\title{
Immigrant relative wages at the Great Recession: Evidence with matched employer-employee data for Spain ${ }^{*}$
}

\author{
Inés P. Murillo Huertas \\ Universidad de Extremadura \\ Facultad de Ciencias Económicas y Empresariales \\ Avda. de Elvas, s/n - 06006 Badajoz \\ Tfno.: 924289300 ext. 86539; e-mail: ihuertas@unex.es \\ Hipólito Simón \\ Universidad de Alicante-IEI-IEB \\ Facultad de Ciencias Económicas y Empresariales \\ Carretera San Vicente del Raspeig s/n - 03690 San Vicente del Raspeig (Alicante) \\ Tfno.: 965903400 ext. 2707; e-mail: hsimon@ua.es
}

\begin{abstract}
The article examines relative wages of immigrants in Spain, with a particular focus on the impact of the Great Recession. The empirical analysis is restricted to men and is based on matched employer-employee microdata and the decomposition techniques of Fortin, Lemieux and Firpo (2011) and Juhn, Murphy and Pierce (1991, 1993). Our results show that the significant native-immigrant wage gap that exists both in terms of average wages and of differentials along the wage distribution is essentially explained by differences in the endowments of observed characteristics so that, in general, immigrants tend to receive a similar wage treatment than Spaniards with analogous observed attributes. On the other hand, the Great Recession has had a noticeable impact on the relative wages of immigrants, given that the significant increase of the native-immigrant wage gap observed during the previous expansionary period was mitigated during the economic downturn due to composition effects arising from the severe employment destruction pattern.
\end{abstract}

Keywords: native-immigrant wage gap; matched employer-employee microdata; Fortin-Lemieux-Firpo decomposition; Juhn-Murphy-Pierce decomposition.

JEL Codes: J15, J31

* This work was supported by the Spanish Ministry of Economy and Competitiveness under Grants CSO2014-55780C3-2-P and ECO2014-53702-P (National R\&D\&I Plan) and by the Instituto de Estudios Fiscales. 


\section{Introduction}

The analysis of the economic behaviour of immigrants has attracted long-standing attention among researchers (see, e.g., Borjas, 1999). Focusing particularly on immigrants' labour market potential assimilation in host countries, a good deal of interest has been devoted to analyze whether immigrants' average wages differ from those corresponding to equally productive native workers (see Constant and Zimmermann, 2013 for an authoritative review). Related to the above, in a context of major concern regarding the socio-economic consequences of the Great Recession for minorities that could suffer from discrimination (Honeys et al., 2012 and Johnston and Lordan, 2014), arguments on whether the economic cycle affects in a different degree to immigrants and natives and how these effects impact on their relative wages are of paramount interest.

The effects of the economic cycle on the immigrant-native wage differential have been traditionally overlooked in the literature, with very few exceptions (see e.g. Ashenfelter, 1970). Later studies suggest, however, that changes in the business cycle might significantly affect immigrants' labour market relative outcomes (see, e.g., Chiswick et al., 1997 and Aydemir, 2003). Thus, the decomposition of workers' labour market outcomes into a secular trend and an economic cycle component reveals that immigrants and natives appear to differ in their response to macroeconomic conditions, even when differences in educational levels are controlled for (Dustmann et al., 2010). Moreover, immigrant-native wage differentials tend to vary along the business cycle on account of the higher responsiveness of the immigrants to changes in labour market conditions (Barth et al., 2004). Focusing particularly on the effects of the Great Recession on minority workers, Biddle and Hammermesh (2013) show that negative shocks have a significant impact on racial and ethnic wage discrimination. In the same line, Orrenius and Zavodni (2010) conclude that the Great Recession has been especially harmful for immigrants, who have experienced more frequently job losses due, among other factors, to their higher sensitiveness to the business cycle, especially for those with lower educational levels.

In this context, the present work examines the immigrant-native wage differential in Spain before and during the Great Recession. To this end, the analysis is based on matched employeremployee microdata that allows us to provide some interesting results regarding how differences in endowments, jobs and firms determine the existing disadvantages in immigrant wages and how these differences have changed across time (e.g. before and with the onset of the economic downturn). Spain constitutes an interesting case-study due to several factors. Thus, as compared to other advanced economies, the Spanish labour market has been particularly hard hit during the Great Recession (see, e.g., European Commission, 2013 and Bentolila et al., 2012). Moreover, immigrants in Spain have been particularly affected by the severe economic worsening during the crisis, as employment destruction has been especially sharp in those manual, low-skilled sectors 
where immigrants tend to be occupied. Consequently, immigrant unemployment rates have dramatically risen, reaching 36.5\% at the end of 2012 (the figure corresponding to natives is 24.2\%: OECD, 2013a). In addition, Spain constitutes an atypical case in terms of migration patterns. By contrast to other typical immigrant-receiving countries, it faced remarkable outflows of workers for a long time. In the 90s, however, the Spanish labour market witnessed its immigrant rates increasing at an outstanding pace, thus comparing to (and even heading the list of) other nations with longer immigrant tradition (United Nations, 2009). Nonetheless, the dramatic impact of the Great Recession on the Spanish labour market has changed greatly this picture. Thus, Spain shows nowadays a negative migration balance, with important reductions in the number of immigrants arriving to the country and notable increases in the out-migration flows (Izquierdo et al., 2015; OECD, 2013 and Larramona, 2013).

Although a number of studies have dealt with the earnings assimilation of immigrants in Spain (see, e.g., Amuedo-Dorantes and de la Rica, 2007; Fernández and Ortega, 2008 and Izquierdo et al., 2009) none of them has considered how immigrant relative wages have evolved during the Great Recession. The objective of this article is to analyze the wage differential between immigrants and natives before and during this economic crisis. For this purpose, a matched employer-employee cross-sectional database providing observations for years 2002, 2006 and 2010 is used. These temporal references allow for a comparative analysis in periods of economic upand downturns where dramatically different migration patterns have been observed, as the migratory flows have shifted from massive immigrant influx to increasing immigrant departures in a short period of time. In order to assess whether the estimated native-immigrant wage gaps are due either to differences in their productive endowments or to a different labour market treatment two different econometric decomposition methodologies are used. The first one is an extension of the methodology proposed by Juhn et al. $(1991,1993)$ adapted for its use with matched employeremployee data. As compared to other techniques recently applied in the literature, this methodology has the advantage of allowing the identification of workplace segregation on both the average immigrant-native wage differential and its evolution over time. ${ }^{1}$ Moreover, in order to extend the analysis to wage differentials all over the wage distribution, a question of high interest as showed by previous studies on the topic (see e.g. Chiswick et al., 2008, Barret et al., 2012 or Butcher and DiNardo, 2002), the decomposition methodology proposed by Fortin, Lemieux and Firpo (2011) is also employed. This technique is based on the unconditional quantile regression

\footnotetext{
1 Other recent techniques such as Nopo's method (Nopo, 2008) have also been used to analyze the Spanish case (see for instance Nicodemo and Ramos, 2012). The reason not to consider Nopo's technique in this study relies on its remarkable sensitiveness to the 'curse' of high dimensionality (i.e. the inclusion of a large number of explanatory variables, as it is the case, can substantially reduce the number of observations found in the common support and, hence, affect significantly the results obtained with the technique).
} 
and has considerable advantages compared to other techniques previously proposed in the literature which also permit the decomposition of differences between distributions (such as DiNardo, Fortin and Lemieux, 1996; Machado and Mata, 2005 and Melly, 2005, 2006), given that it permits to quantify the individual impact of each explanatory variable on the wage differential between natives and immigrants throughout the wage distribution.

The rest of the article is organized as follows. Section two compiles an overview of the main contributions dealing with natives-immigrants wage gap in an international context. The database is described in section three. Section four is devoted to outline the econometric techniques involved in the decomposition of the native-immigrant wage differential. Section five discusses the main empirical results and, finally, section six concludes.

\section{Literature review}

The vast literature dealing with the economic performance of immigrants in host countries has typically focused on the comparison between foreign-born and native workers with similar observed characteristics. Following Chiswick (1978) and Carliner (1980) seminal contributions, the potential assimilation of immigrants over time in their destination countries has been the core of this research. In this vein, a good deal of studies relying on cross-sectional data shows that although the wages of newly arrived immigrants are significantly lower than those corresponding to comparable native workers, as immigrants stay and accumulate destination country's specific human capital their wages tend to catch, and even to exceed in some cases, those earned by natives $^{2}$ (see, as representative contributions of the extensive empirical evidence regarding this topic, Baker and Benjamin, 1994; Borjas, 1994; Friedberg, 2000 or LaLonde and Topel, 1991). In contrast to this assimilation perspective, it has also been argued that persistent wage differentials between natives and immigrants might arise as a result of discriminatory treatment of the latter (see more details in Chiswick et al., 2005). Thus, if employers perform on their dislike of immigrants -in the spirit of Becker (1957) "taste for discrimination"- or treat immigrants following statistical discrimination criteria (Phelps, 1972), then wages for natives and immigrants with the same observed productive endowments would differ, even although the gap narrows with the number of years since migrating of the latter. In this regard, empirical evidence from studies that examine the origin of differences in average wages between natives and immigrants suggests that other elements different than the length of the stay of immigrants in the host country, such as the

\footnotetext{
2 As noted by Borjas (1985), studies relying on cross-sectional data are prevented from disentangling assimilation and cohort effects. As a consequence, estimations about how immigrant wages evolve over time might be upward biased if a decrease in the skills of successive arrival cohorts occurs. To allay this concern, the focus in this literature shifted to the use of longitudinal and panel datasets. In this regard, empirical studies conclude that wages corresponding to
} 
age of the immigrants at the arrival, their national origin or the particular year of arrival are important factors in explaining why immigrants' average wages lay behind those corresponding to observationally equivalent native workers (Constant and Zimmermann, 2013). On the other hand, regarding the role of unobservables, Nanos and Schluter (2014) provide evidence on the significance of differences in search frictions, reservation wages and productivities between natives and immigrants in determining their wage differential, even once discrepancies in occupations, age and nationality are controlled for.

A particularly important element for its contribution to the existing disadvantages in immigrants' earnings is their occupational and workplace segregation (Kaufman, 2010). The availability of matched employer-employee databases over the last few decades has allowed to obtain empirical evidence on the relevant impact of the relative segregation of immigrants in certain segments of the labour market on their wages (see, e.g. Bayard et al., 1999 and, among the most recent contributions, Barth et al., 2012 and Carneiro et al., 2012). Thus, for example, Aslund and Skans (2010) conclude that immigrants in Sweden are not randomly sorted across establishments and occupations and that they are overexposed to foreign-born counterparts, with this feature leading to statistical significant effect on average wages. Similarly, Barret et al. (2012) provide evidence on the significant wage effects of the unequal distribution by occupations of natives and immigrants from the European Union's New Member States in the Irish labour market. Likewise, native-immigrant wage differentials in Canada are notably influenced by immigrant sorting between and within establishments, as well as by the type of jobs they are able to get access to (Aydemir and Skuterud, 2008 and Yoshida and Smith, 2005). Finally, wage differentials between French native workers and national-born workers with foreign-born parents are also primarily due to occupational segregation of the latter (Aeberhardt and Pouget, 2010). As regard the origin of this immigrant labour segregation, Strömgren et al. (2014) analyze the socioeconomic factors behind this phenomenon for the case of Sweden and conclude that workplace segregation is conditioned by residential segregation, having the intermarriage with a native the effect of reducing workplace segregation only for the case of immigrant men. In a similar vein, Ellis et al. (2004) and Hellerstein et al. (2011) also emphasize the importance of neighbourhood segregation in determining immigrant's workplace segregation for the case of the United States.

The relevance of labour segregation also underlies much of the current concern on how foreign-born workers fare in the Spanish labour market. Empirical studies for Spain suggest in particular that immigrants experience significant occupational segregation from the native-born

natives and those earned by latest cohorts of immigrants with equal endowments might never converge - see, for example, Dowhan and Duleep (2002) for USA, or Constant and Massey (2003) for Germany-. 
population and that this segregation tends to persist over time (Alcobendas and Rodríguez-Planas, 2009; Alonso-Villar and del Río, 2013 and Amuedo-Dorantes and De la Rica, 2011). Moreover, evidence is provided on the important obstacles that immigrants encounter in their attempt to achieve skilled occupations (Bernardi et al., 2011) and on the severe occupational downgrading they usually witness with respect to their countries of origin (Simón et al., 2014). These findings are of salient interest insofar as, consistent with other studies on this topic, occupational and workplace segregation has been found to explain to a considerable degree the existing wage differentials between natives and immigrants in Spain (García-Pérez et al., 2012 and Simón et al., 2008).

Regarding the question of how immigration affects natives' labour market perspectives much of the debate has been centred on the potential substitutability between immigrant and native workers with the same education and experience. If foreign and native workers do not compete for the same occupations then the entry of new immigrants might have null impact on natives' employment prospects, barely affecting their average wages. Imperfect substitutability has been documented for the case of Germany (D’Amuri et al., 2010), the US (Card, 2007; Ottaviano and Peri, 2012 and Raphael and Smolensky, 2009) and the UK (Manacorda et al., 2012), although changing immigrant composition effects could potentially bias this result (Ruist, 2013). Focusing on the Spanish case, Amuedo-Dorantes and De la Rica (2011) also find no significant effects of migration on natives' employment outcomes and that, accordingly, native workers appears to adjust to increasing immigrant labour supply by changing their task specialization and hence their occupational distribution. Moreover, this relocation pattern varies with the business cycle, given that the occupational relocation of Spanish native workers in response to immigration observed during the previous expansionary period does not seem to persist during the Great Recession, being the earlier immigrant workers those who adjust their employment choices to absorb new immigrants during the economic downturn (De la Rica and Polonyankina, 2014).

Related to the above, it is worth mentioning that differences in responses of immigrants and natives to the business cycle are in fact of major interest in order to properly understand the nature of immigrant-native wage differentials (see, e.g. Barth et al., 2004). Earlier studies focusing on the cyclicality of immigrants' relative earnings conclude that changes in the phase of the economic cycle do not seem to derive in changes in wage discrimination once the composition effect has been controlled for (see, e.g., Ashenfelter, 1970). Moreover, the phase of the economic cycle at the entry as well as at the survey year have been proved to significantly affect immigrants' labour force participation, employment and wages (Aydemir, 2003). In the same line, it has also been documented that immigrant responses to macroeconomic conditions are unequal than those of native workers (Chiswick et al., 1997) and that their relative wages are tied to host countries' 
unemployment trends (Barth et al., 2006). For the particular case of the effects of the Great Recession, Orrenius and Zavodni (2010) show that male immigrants in the United States seem to be more sensitive to the economic cycle than natives, mainly due to their productive characteristics and their overrepresentation in pro-cyclical sectors. On the other hand, Dustmann et al. (2010) provide evidence on the larger unemployment cyclical responses for immigrants relative to natives within skill groups, albeit no substantial different patterns apparently exist with regard to wages.

\section{Data}

This research is based on the microdata of the 2002, 2006 and 2010 waves of the Encuesta de Estructura Salarial (Survey of Earnings Structure; hereafter, EES). This survey is conducted by the Spanish National Statistics Institute and is the sample for Spain of the European Structure of Earnings Survey, a survey conducted in the member countries of the European Union in accordance with a harmonized methodology. It is a nationally representative survey on firms which covers employees registered in the Social Security system throughout the month of October at establishments of any size belonging to the general scheme of the Social Security system and whose economic activity is framed in sections B to S of the sectoral classification NACE 2009. Therefore, it encompasses the bulk but not the total of the private sector given that it does not cover certain specific sectors such as agriculture and domestic service (and, to the wave of 2010, the public sector). ${ }^{3}$ The design of the survey corresponds to a two-stage sampling of employees working in firms registered in the Social Security system, so one of its most important features is the inclusion of matched employer-employee microdata (i.e. observations for various employees in each establishment).

The EES has been designed as independent cross-section databases which are conducted every four years, being currently four available waves (1995, 2002, 2006 and 2010). Their coverage has been growing with time, as the wave of 2002 included for the first time non-market services (education, health and other social activities); the wave of 2006 establishments with fewer than 10 employees and the wave of 2010 public administration and defence and compulsory social security. Similarly, information on the characteristics of workers has been also increasing over time and the wave of 2002 included for the first time variables regarding their nationality and the

\footnotetext{
3 The lack of information in the survey about non-employed workers precludes the application of standard techniques of selection bias correction à la Heckman in the estimates (Heckman, 1979) and, therefore, to examine the influence of selection on employment on the wage gap. Nonetheless, this issue is usually more relevant for women, being this empirical analysis restricted to men. In addition, this limitation may be negligible in the context of the study developed in this research, given that participation rates of native and immigrant males are relatively high in Spain. Thus, according to De la Rica et al. (2014), activity rates are around $85 \%$ for male immigrants being $80 \%$ for native males.
} 
performance of supervisory tasks. Due to this circumstance, the empirical analysis is restricted to the waves of 2002, 2006 and $2010 .^{4}$

The survey provides detailed information on wages and worker characteristics (nationality, gender, age and education); jobs (occupation, tenure, type of contract, full- or part-time work and supervisory tasks) and firms (sector, size, type collective agreement and region). Wage information includes various components and covers different time references. The wage concept used in this research is the gross hourly wage, calculated from the wage corresponding to a representative month (October), divided by the number of hours worked in that month. In its calculation any payment by companies, including commissions, bonuses for night work and weekends, as well as overtime work, has been incorporated.

The empirical analysis is restricted to male workers aged less than 65 , as it is usual in other studies on the topic. The main reason that justifies this proceeding is that the markedly different patterns of labour market performance of immigrant men and women advices against a unique treatment for both genders (see Adsera and Chiswick, 2007). In addition, the usual lack of information about real experience in the databases (and the EES is not an exception) forces the use of potential experience which represents a serious shortcoming when dealing with women due to career interruptions because of maternity leave. The explanatory variables considered in the empirical analysis include characteristics of both individuals and their jobs and firms. Regarding the former, they are controls related to the highest level of education (primary, secondary or tertiary education) and age (less than 30 years, between 30 and 45 years and more than 45 years). The characteristics of the jobs are occupation (nine categories for major occupational groups); years of tenure in the current job and its quadratic form; type of contract (permanent or fixed-term); full time or part time job and the performance of supervisory tasks. Finally, firm attributes are sector (twelve categories); size (six strata); region and the type of collective agreement (distinguishing between firm agreement, national sectoral agreement and infra-national sectoral agreement).

It should be noted that certain shortcomings of the EES could potentially affect the results of the empirical analysis. Thus, it contains exclusively workers with legal status and it does not cover certain segments of the labour market where the presence of immigrant males is significant, as the primary sector. ${ }^{5}$ In this sense the comparison with alternative datasets which cover also immigrants in illegal situation and the whole Spanish economy, such as the Living Conditions Survey, suggests that the ESS apparently tends to underestimate, albeit only slightly, the average wage differential between native and immigrant workers (Simon et al., 2008), a circumstance to be

\footnotetext{
${ }^{4}$ It has been proved that the lack of coverage of firms with fewer than 10 employees in the 2002 wave of the ESS has no significant effects on the results provided in section 4 . The outcomes of these robustness checks are available from the authors at request.
} 
considered in the interpretation of results. On the other hand, another relevant limitation of EES data is that it does not include information about the year of arrival of immigrants to Spain. As a consequence, the potential assimilation of immigrants resulting from the upgrade over time of their human capital cannot be accounted for in the analysis. ${ }^{6}$ Despite all these limitations and their potential impact on the estimated results, the EES has some advantages over other surveys also used in the analysis of the wage gap between natives and immigrants for the Spanish case, such as the Muestra Continua de Vidas Laborales (Continuous Sample of Working Lives; MCVL) - see for example, Nicodemo and Ramos (2012) -. Thus, although the MCVL presents a larger size and contains highly reliable administrative registers and longitudinal information, the EES independent cross-sections have a number of advantages that make them very attractive to the type of analysis developed in the article. So, the EES contains matched employer-employee data that provide rich information on different variables that are crucial in explaining the wage disadvantage of immigrant men and its evolution over time and do not exist or suffer from severe measurement error in the MCVL (namely fixed firm effects, educational level and occupation). Moreover, unlike the MCVL, the EES contains uncensored wages without maximum and minimum limits and includes information regarding the number of hours worked that permits the use of hourly wages as dependent variable.

Those observations with missing values on key variables as well as those for individuals aged over 65 years or with hourly wages less than one euro or greater than two hundred euros have been filtered. Moreover, firms with less than two observations were excluded from the sample in order to allow the correct identification of firm fixed effects in the econometric estimates. Finally, in order to use a homogeneous sectoral coverage, observations corresponding to section O of NACE-2009 (Public administration and defence, compulsory social security) have been removed from the 2010 wave. As is usual in the literature workers with nationality other than Spanish are considered to be immigrants. This procedure has certain limitations as a non negligible portion of immigrants in Spain has acquired the Spanish nationality over time (according to data from the Labour Force Survey, men with dual nationality (Spanish and foreign) accounted for 0.4\%, $0.6 \%$ and $1.2 \%$ of total men employed in Spain in 2002, 2006 and 2010, respectively; for comparative purposes, the proportion of males with only foreign nationality in the same periods was $6.0 \%, 12 \%$ and $12.3 \%$ ). Nonetheless, it is not possible to use country of birth instead of nationality to define the category of immigrant due to EES constraints having this same definition

\footnotetext{
5 Available evidence suggests that the proportion of immigrant employees working in an irregular situation in Spain is between 15\% and 20\% of the total (Instituto Nacional de Estadística, 2014 and Amuedo et al., 2013).

${ }^{6}$ According to previous studies, immigrants usually experience a wage disadvantage when they arrive in a new country due to the limited transferability of the human capital they have acquired in their home country for reasons such as the lower quality of the educational systems or different cultural backgrounds. Over time immigrant wage levels tend to
} 
been usually used in most of previous studies on immigration and its effect on the Spanish labour market (see for example Amuedo-Dorantes and de la Rica, 2007; Carrasco, Jimeno and Ortega, 2008 and González and Ortega, 2011). The final samples are formed by 2,875 immigrant men and 75,549 native men in 2002, 6,876 and 75,319 in 2006 and 6,584 and 87,875 in 2010.

\section{Methodology}

In the empirical analysis two econometric methodologies have been used in order to decompose wage differences between natives and immigrants males. The first is an extension of the Juhn-Murphy-Pierce methodology (Juhn et al., 1991) adapted to its use with matched employer-employee data, which permits a detailed decomposition of the differential between the average wage of native workers and immigrants, as well as of its evolution over time. The second is the methodology proposed by Fortin, Lemieux and Firpo (2011) which provides a detailed decomposition of the wage differences throughout the wage distribution. Both techniques are described below.

\subsection{Juhn-Murphy-Pierce decomposition}

First, we use an extension of the Juhn et al. (1991) decomposition suggested by Blau and Kahn (1992), specifically adapted to be used with matched employer-employee data, following the hints of Gartner and Stephan (2004). This technique departs from the estimation of the following semi-logarithmic wage equation:

$$
w_{i j}=X_{i} \beta+\varepsilon_{i j}+a_{j}
$$

wherein $w_{i j}$ is the natural log of hourly wage of individual $i$ in workplace $j ; X_{i}$ is a vector of controls including individuals' characteristics and those of their jobs and the companies employing them; $\beta$ is a vector of parameters to be estimated (including an intercept); $\varepsilon_{i j}$ is a stochastic error term and $a_{j}$ is an error component corresponding to workplace $j$ and invariant for all the individuals working in the same workplace.

Following Oaxaca and Ransom (1994) and Neumark (1998) recommendation we use as reference wage structure in the decomposition that corresponding to both groups so equation (1) is estimated for the pool of workers (i.e. natives and immigrants). Identification of the workplace effects is guaranteed, given that there is more than one observation per workplace in the dataset. Since the result of the Hausman's contrast indicates that workplace specific effects are correlated with the rest of the explanatory variables in equation (1), it is estimated by fixed effects (which is with the native population (see inter alia, Chiswick, 1978; Chiswick and Miller, 2005 and Friedberg, 2000). 
equivalent to estimating by ordinary least squares with a set of workplace dummies). Relying on the properties of the ordinary least squares estimator, after the estimation of equation (1) with the pooled data of year $\mathrm{A}$ and having obtained the values of $\hat{\beta}^{A}, \sigma^{\mathrm{A}} \mathrm{y} \eta^{\mathrm{A}}$, the average wage of the subgroup of workers $\mathrm{s}(\mathrm{s}=$ natives or immigrants) in year A can be expressed as:

$$
\bar{w}_{s}^{A}=\bar{X}_{s}^{A} \hat{\beta}^{A}+\sigma^{A} \bar{\theta}_{s}^{A}+\eta^{A} \bar{\lambda}_{s}^{A} \quad \text { where } \bar{\theta}^{A} \sim(0,1), \bar{\lambda}^{A} \sim(0,1)
$$

where the superscript $A$ is for year A (note that subscripts $i$ and $j$ have been omitted in the equation for ease of presentation); $\bar{w}_{s}^{A}$ stands for the mean natural $\log$ of the hourly wage of a given group s; $\bar{X}_{s}^{A}$ is a vector of the average of the set of explanatory variables for group s; $\hat{\beta}_{s}^{A}$ is the vector of coefficients estimated with equation (1) and the pooled data of year $A ; \sigma^{A}$ is the standard deviation of wage residuals of the pool of workers; $\bar{\theta}_{s}^{A}$ is the average standardized residual of group $s ; \eta^{A}$ is the standard deviation of workplace effects of the pool of natives and immigrants and $\bar{\lambda}_{s}^{A}$ is the average standardized workplace effect of group s.

Using the pooled wage structure as the market price reference in the decomposition, the wage gap between natives and immigrants in year A can be written as follows:

$$
D^{A}=w_{n}^{A}-w_{i}^{A}=\left(X_{n}^{A}-X_{i}^{A}\right) \beta^{A}+\left(\theta_{n}^{A}-\theta_{i}^{A}\right) \sigma^{A}+\left(\lambda_{n}^{A}-\lambda_{i}^{A}\right) \eta^{A}=\Delta X^{A} \beta^{A}+\Delta \theta^{A} \sigma^{A}+\Delta \lambda^{A} \eta
$$

where the subscript $n$ is for natives and $i$ for immigrants and a $\Delta$ prefix denotes the average difference between natives and immigrants in the subsequent variable.

In brief, equation (3) provides a decomposition of the native-immigrant wage gap that quantifies the extent to which average wage differences between natives and immigrants are related to (a) differences in observed characteristics, (b) the influence of unobserved elements and (c) the influence of workplace-related factors. More specifically, the first term on the right-hand side of the equation corresponds to the portion of the wage differential attributable to differences in the observed characteristics between the two groups $\left(\bar{X}_{m}^{A}-\bar{X}_{f}^{A}\right)$, valued at market prices $\left(\hat{\beta}^{A}\right)$, which coincides with the 'explained' component of the standard Oaxaca-Blinder decomposition. The second term measures the influence of the unobserved factors in the model. This component comprises the effect of unobserved ability, motivation and discrimination, among others, and corresponds to the impact of differences by nationality on the average standardized residual $\left(\bar{\theta}_{m}^{A}-\bar{\theta}_{f}^{A}\right)$ multiplied by the money value per unit difference in the standardized residual $\left(\sigma^{A}\right)$, which determines the specific wage penalty suffered by the disadvantaged group. Finally, the third term estimates the influence of workplace-related factors. This term is taken as a product of the difference in the average standardized workplace effect of natives and immigrants $\left(\bar{\gamma}_{m}^{A}-\bar{\gamma}_{f}^{A}\right)-$ which 
measures the intensity of immigrant segregation into comparatively low-wage workplaces - and the dispersion of wage differentials across workplaces $\left(\eta^{\mathrm{A}}\right)$ - which determines the degree of the wage penalty for immigrants resulting from this segregation -.

On the other hand, the difference in the magnitude of the native-immigrant wage gap between two years (A and B) may be expressed as follows:

$$
D^{A}-D^{B}=\left(\Delta \bar{X}^{A}-\Delta \bar{X}^{B}\right) \hat{\beta}^{A}+\Delta \bar{X}^{B}\left(\hat{\beta}^{A}-\hat{\beta}^{B}\right)+\left(\Delta \bar{\theta}^{A}-\Delta \bar{\theta}^{B}\right) \sigma^{A}+\Delta \bar{\theta}^{B}\left(\sigma^{A}-\sigma^{B}\right)+\left(\Delta \bar{\lambda}^{A}-\Delta \bar{\lambda}^{B}\right) \eta^{A}+\Delta \bar{\lambda}^{B}\left(\eta^{A}-\eta^{B}\right)
$$

According to equation (4), temporal changes in the magnitude of the immigrant-native wage gap can be explained by inter-temporal differences in six different factors. The first one captures the effect in the gap of changes over time in the relative observed characteristics of natives and immigrants. The second term reflects the contribution of differences over time in the market prices of those characteristics. The third term measures the impact of inter-temporal differences on the relative positions of natives and immigrants within the residual wage distribution (after controlling for measured characteristics and workplace effects). The fourth term isolates the impact of temporal changes in wage residual dispersion (remaining constant the relative position of the average native and immigrant worker in the residual distribution). The fifth term captures the impact of temporal differences in the extent of native workplace segregation. Finally, the sixth term measures the effect of differences in the dispersion of workplace wage differentials.

\subsection{Fortin-Lemieux-Firpo decomposition}

Fortin, Lemieux and Firpo (2011) have recently proposed a technique which enhances the development of the empirical decompositions of differences between two distributions of a variable. In the end, this technique provides a breakdown of the differences between distributions in the value of any distributional statistic (as the value of a quantile or an inequality index) based on the differences in the endowments of characteristics and in its returns respectively. This is a procedure which has considerable advantages compared to other techniques previously proposed in the literature which also permit the decomposition of differences between distributions based on construction of counterfactual distributions (DiNardo, Fortin and Lemieux, 1996; Juhn, Murphy and Pierce, 1993; Machado and Mata, 2005 and Melly, 2005, 2006). Thus, whereas the latter techniques consist of aggregated decompositions which, aside from partial exceptions, provide exclusively the separate effects of the characteristics and returns components, Fortin, Lemieux and Firpo's methodology provides a detailed decomposition which allows, in addition, ascertaining the individual contribution of each explanatory variable to both components.

This methodology is based on the estimation of a regression in which the independent variable (the wage) is substituted by a transformation of the same, the recentered influence function; 
hereinafter RIF) so that subsequently a standard Oaxaca-Blinder decomposition can be developed for any distributional statistic based on the regression results.

The influence function measures the effect on distributional statistics of small changes in the underlying distribution. Thus, for a given distributional statistic of the distribution $F_{W}, v(F)$, this function measures the importance of each observation in shaping the value of this statistic. Fortin, Lemieux and Firpo (2011) suggest using a recentered version of the influence function having added the statistic of interest, $R I F(W)=v(F)+I F(W)$, since it has as expected value the actual statistic $v(F)$ (insofar as the expectation of the function of influence with respect to distribution of $W$ is, by definition, zero).

In the case of the quantiles $Q_{\theta}$ of the unconditioned marginal distribution $F_{W}$, the function of influence, $I F\left(W, Q_{\theta}\right)$, is defined in the following way:

$$
I F\left(W / Q_{\theta}\right)=\frac{\theta-l\left\{W<Q_{\theta}\right\}}{f_{W}\left(Q_{\theta}\right)}
$$

Where $l\{\}$ is an indicator function and $f_{W}$ is the function of density of the marginal distribution of $W$ evaluated in $Q_{\theta}$.

Given that the function of recentered influence, $R I F\left(W, Q_{\theta}\right)$, is equal to $Q_{\theta}+I F\left(W, Q_{\theta}\right)$, then the following is fulfilled:

$$
\operatorname{RIF}\left(W / Q_{\theta}\right)=Q_{\theta}+\frac{\theta-l\left\{W<Q_{\theta}\right\}}{f_{W}\left(Q_{\theta}\right)}
$$

The RIF function may be computed empirically in the case of the quantiles by means of a local inversion following calculation of the dummy variable $l\left\{W<Q_{\theta}\right\}$ (which specifies whether the value $W$ is higher or lower than $Q_{\theta}$ ), the estimation of the quantile of the sample $Q_{\theta}$ and the estimation by means of kernel density functions of the corresponding density function $f_{W}$ evaluated in $Q_{\theta}$.

Following calculation of the RIF function for the quantile, a value is provided for the transformed variable for each observation of the sample. Insofar as the effect of the change in distribution of an explanatory variable in the quantile may be expressed ceteris paribus, as the average partial effect of that variable in the conditioned expectation on its RIF function, and assuming that the conditioned expectation of the RIF function may be modelled as a linear function of the explanatory variables, these values may be used for estimation by means of ordinary least squares of a regression of the RIF variable in a vector of explanatory variables. The 
estimated coefficients may be interpreted then as the effect of an increase in the average value of an explanatory variable in the distribution quantile (Firpo, Fortin and Lemieux, 2009).

The estimated coefficients of that regression may be used for calculation of a standard Oaxaca-Blinder decomposition of different quantiles of the distribution. In the development of the decomposition the wage structure of the pool of the two groups involved in the comparison has also been used as the reference wage structure.

Consequently, the decomposition takes the following form:

$$
\Delta_{Q_{\theta}}=\left(\bar{X}^{n}-\bar{X}^{i}\right) \hat{\gamma}_{Q_{\theta}}^{*}+\left\{\bar{X}^{n}\left(\hat{\gamma}_{Q_{\theta}}^{i}-\hat{\gamma}_{Q_{\theta}}^{*}\right)+\bar{X}^{i}\left(\hat{\gamma}_{Q_{\theta}}^{*}-\hat{\gamma}_{Q_{\theta}}^{n}\right)\right\}
$$

Wherein $\Delta_{Q_{\theta}}$ is the difference in the quantile $Q_{\theta}$ (or, as has been indicated, in any other statistic) of the wage distributions of natives and immigrants males, respectively; $\bar{X}^{r}$ and $\bar{X}^{h}$ are the average observed characteristics for natives and immigrants and $\hat{\gamma}_{Q_{\theta}}^{n}, \hat{\gamma}_{Q_{\theta}}^{i}$ and $\hat{\gamma}_{Q_{\theta}}^{*}$ are the estimated coefficients following regression of the RIF variable of the quantile $Q_{\theta}$ on the group of explanatory variables for natives, immigrants and the pool of both groups respectively. The first component of the right-hand side of the equation represents the effect on the differential between distributions caused by differences in characteristics (or 'explained' component) whereas the second corresponds to the effect of the coefficients (or 'unexplained' component). As previously refereed, the contribution of each explanatory factor can be observed in the decomposition results.

\section{Results}

\subsection{Descriptive evidence}

Table 1 and Figure 1 contain information on the wage gap between native and immigrant men in Spain, measured in logarithms of the gross hourly wage (Figure A.1 in the Appendix provides the corresponding density functions of the wage distributions for each group). A significant disadvantage in average wages of immigrants against natives can be observed throughout the whole period (i.e. $0.204 \log$ points in 2002, 0.244 in 2006 and 0.259 in 2010). Moreover, the wage differential has an increasing profile along the whole wage distribution, with the exception of the right tail, where it tends to decrease. As regards to changes over time, the magnitude of the gap tends to increase along the entire period. During the economic expansion the increase was more significant (with a change of $0.04 \log$ points between 2002 and 2006) and occurred mainly in the upper part of the wage distribution. By contrast, during the economic downturn the growth had a lower magnitude (0.015 log points) and took place almost exclusively in the lower part of the distribution, decreasing in the right tail of the distribution.

[Table 1 about here] 
[Figure 1 about here]

Table A.1 in the Appendix shows, in turn, how native and immigrant men in Spain differ significantly in their relative observed characteristics, as well as in its evolution over time. So, without being exhaustive, the comparison between the endowments of characteristics of native and immigrant men reveals that the latter are on average younger (and have hence lower levels of potential work experience), and have also lower endowments of education and seniority in the firm; higher incidence of temporary contracts; greater presence in occupations associated with lower levels of qualification and without supervisory responsibilities and, finally, greater representation in smaller firms and firms covered by sectoral agreements. Almost all these characteristics are generally associated to lower wages in the Spanish labour market (see for instance, Davia and Hernanz, 2002 and Card and De la Rica, 2006 for the influence of the type of contract and the type of collective agreement on wages). On the other hand, it must be noted that the aforementioned immigrants' disadvantages increased during the economic expansion in some of these dimensions (including, for instance, their presence in semi- and unskilled occupations and in jobs without supervisory tasks), whereas some of them tended to decrease during the economic downturn (i.e. education and occupation). Finally, the composition of immigrants in Spain according to their geographical origin is rather stable over time, although the shares of immigrants from Europe and Latin America tended to increase slightly (in the latter case, with the exception of the period 2006-2010) and, consequently, the share of immigrants from the rest of the world tended to decrease. ${ }^{7}$

Another important question arising from descriptive statistics is how the inflow of immigrant workers to the Spanish labour force between 2002 and 2006 and the subsequent outflow of foreign workers between 2006 and 2010 (the percentage of immigrant workers varies from $3.7 \%$ in 2002 and $8.4 \%$ in 2006 to $6.9 \%$ in 2010) might condition the results of the study. This concern is one of a major interest given the selection and composition effects that might derived from changes in the macroeconomic conditions over the analyzed period. In this regard, additional information about the proportion of Spanish immigrants in different labour market status over time and about some observed characteristics of all Spanish-based immigrants is provided in table A.2 in the Appendix combining EES and Labour Force Survey (LFS) information (as the former only covers wage earners). According to this information, and consistent with the fact that foreign men in Spain are mainly working immigrants, immigrant men exhibit high rates of

\footnotetext{
7 Although recent international studies suggest that labour performance of immigrants depend on certain characteristics of their countries of origin such as the level of development, all immigrants are considered as a group in the empirical analysis. The reasons are that, unfortunately, the very limited information provided by the EES about the region of origin of immigrants does not allow to distinguish between advanced and emerging economies, on the one hand, and the very low size of the samples of immigrants in the EES when disaggregating according to their region or origin, on the other.
} 
activity and employment, actually exceeding those of Spanish men (Table A.2). The participation rate of immigrant males has actually remained rather stable at around $85 \%$ of the working age population over the whole analyzed period so it has been barely affected by the crisis. This circumstance is consistent with the weak response of the immigrant male activity rate to changes in the economic cycle documented by Montero and Regil (2015) for the Spanish case ${ }^{8}$. All in all this evidence suggests that discouraged worker effects are no prevalent regarding the labour force participation of immigrant males in Spain as a result of the crisis (in the same vein, added worker effects are also expected not to be prevalent as previous studies suggest that they tend to be relevant in practice mostly for females).

Regarding the type of immigrant workers flowing in an out of Spain during the examined period, Table A.3 shows that during the first phase of the Great Recession (e.g. the period 20082010) migration inflows remained high and migration outflows increased only slightly so that most of the significant changes in the nature of the migration flows occurred after 2010 (Izquierdo et al., 2015). For the expansionary period 2002-2007, the evidence in that study shows that immigrants arriving to Spain mostly came from Europe and Latin America being young, low educated males. By contrast post-crisis immigrants come from the rest of the world and have higher ages and levels of education so that after the crisis the share of both older and more educated workers increases among the stock of immigrants in Spain. This evidence on a positive selection of foreign immigrants in observables such as age and education and a negative selection of foreign outmigrants in terms of education observed after the onset of the Great Recession is in general consistent with changes observed over time in the characteristics of immigrants in EES samples.

Summing up, as available evidence suggests that the participation rate of immigrant men in Spain does not tend to respond to cyclical conditions and that the main impacts of the economic crisis on migration inflows and outflows ocurred in the final years of the crisis (e.g. after 2010, hence after the period examined in the article), we expect that the effect of the selection of immigrants into the workforce related to unobservable factors as a consequence of the crisis could plausibly not be very relevant during the period covered by the article and not affect in a significant way the results presented in this study. On the other hand, the comparison with other data sources shows that our EES samples reflect quite well the changes in the characteristics of immigrants that occurred during the period examined as regards relevant observable elements such as age, education or region of origin.

\subsection{Econometric decompositions}

\footnotetext{
8 It is worth to mention that, by contrast, table A.2 also shows how the crisis has had a noticeable effect on employment and unemployment rates of male immigrants. The reason is that the heavy employment destruction pattern derived from the crisis has had a comparatively greater impact on immigrants than on natives with similar characteristics (for a detailed analysis see Motellón and López-Bazo, 2015).
} 
Table 2 contains the results of the application of the extension of the Juhn, Murphy and Pierce $(1991,1993)$ proposal to decompose average wages differentials. The first row provides the value of the wage gap between native and immigrant men and the rest of the rows the figures corresponding to the different terms of the decomposition (note that a positive value for a specific factor indicates an unfavourable effect for the relative wages of immigrant men). Three specifications of the wage equation have been considered: the first one includes as unique explanatory variables sociodemographic characteristics of individuals (model 1); the second one incorporates job and firm attributes 1 (model 2) and the third specification considers firm fixed effects instead of firm attributes (model 3). Note that the results of models 1 and 2 are equivalent to those of a standard Oaxaca-Blinder decomposition into two components (characteristics and returns), whereas model 3 incorporates to the results of the decomposition the third component of the right side of equation (3).

Evidence from model 1 suggests that whereas part of the wage gap between native and immigrant men in the Spanish labour market is due to the worst relative endowments of immigrants as regards observed productive characteristics such as education and age (the characteristics component explains between $44 \%$ and $55 \%$ of the gap, depending on the year), a relevant portion of the gap is explained by the lower returns of those characteristics for immigrants (conversely, the returns component explains between $45 \%$ and $56 \%$ of the gap). Yet, when a more complete set of controls is considered (model 2), the bulk of the wage gap is explained by differences in endowments of observed characteristics (the characteristics component accounts in this case for more than $90 \%$ of the raw wage gap every year) whereas the unexplained part of the gap has only a marginal effect. The detailed results of the decomposition show, in turn, that the lower average tenure of immigrants and their higher presence in low-wage occupations are particularly important elements in explaining the wage gap (the sum of both factors justify between $60 \%$ and $70 \%$ of their wage disadvantage, depending on the year). This evidence also shows that in general immigrants tend to exhibit unfavourable relative endowments of all the characteristics considered (being the main exception the region of residence, which suggests that in the case of Spain immigrants tend to be located in high-wage regions).

When firm fixed effects are included as explanatory variables (model 3), differences in the endowments of observed characteristics, captured by the first term of the decomposition, continue to justify the bulk of the average wage differential between native and immigrant workers (between two thirds and $90 \%$ of the gap, according to the year). Unobservable factors justify, in turn, an almost negligible part of the wage gap (the second component of the decomposition takes values lower than $0.01 \log$ points). Given that, by the nature of the decomposition applied, the value of this component provides the average wage differential between native and immigrant men with the 
same characteristics working in the same firm, this finding therefore suggests that in general Spanish firms tend to pay similar wages to natives and immigrants with similar observed characteristics, which apparently precludes the existence of wide-ranging direct discrimination against immigrants in the Spanish labour market. Finally, the third component of the decomposition reveals that the unequal distribution by firms of native and immigrant workers is a factor with a notable influence on the wage differential, explaining a significant proportion of the gap (between 0.040 and $0.095 \log$ points or between $20 \%$ and $47 \%$ of the average wage differential, depending on the year). Accordingly, the relative segregation of immigrant men in low-wage firms is a relevant argument in explaining their lower relative wages. Moreover, the influence of this factor increases significantly in 2010, almost doubling its effect in previous years, suggesting that the economic crisis has exacerbated the segregation of immigrants into low-wage establishments.

\section{[Table 2 about here]}

From a time perspective, Table 3 shows the results of the decomposition of the change of the native-immigrant wage gap between the periods 2002-2006 and 2006-2010 following equation (4). The first row of the table contains the change over time of the wage differential, whereas the remaining rows show the contribution of the different terms of the decomposition (a positive value indicates that the factor contributes to increase the gap). The significant increase of the native-immigrant wage gap between 2002 and 2006 (0.040 log points) is due to the joint effect of several factors. On one hand, the worsening of the relative endowments of observed characteristics of immigrants, with a prominent role of changes in the distribution by occupation and, to a lesser extent, by jobs with supervisory tasks (both elements explain jointly more than the half of the increase of the wage gap according to results of both models 2 and 3). On the other hand, and focusing on the results derived from model 3 , the intensification of the segregation of immigrants into low-wage firms (the fifth component of the decomposition takes a value of 0.014 $\log$ points) as well as the effect of unobserved factors (the third component of the decomposition takes a value of $0.011 \mathrm{log}$ points, indicating that the average position of immigrants in the residual wage distribution worsened during the period) Yet, the effect of these factors was just partially

\footnotetext{
${ }^{9}$ Note that firm fixed-effects (model 3) are more important in explaining the average native-immigrant wage gap than observable firm characteristics available in the EES (model 2). This result is sound insofar as according to the literature inter-firm wage differentials for workers with similar observed characteristics can arise theoretically for a wide variety of reasons, such as compensating wage differentials; sorting of workers by ability; random variation of wages due to costly information; efficiency wages payments or rent-sharing processes (Groshen, 1991). Actually, empirical analyses based on matched employer-employee databases suggest that although observable firm characteristics as those available in the EES (i.e. region, activity sector, firm size and collective agreement) are relevant explanatory factors of wages, they tend to explain only partially observed employer effects (Lane et al., 2013 and Simón, 2010).
} 
offset by changes in the returns of the observed characteristics (the second component of the decomposition takes values between -0.009 and-0.012 log points, depending on the model).

Regarding the period 2006-2010, the relatively lower increase of the native-immigrant wage differential (0.015 log points compared to $0.040 \log$ points in the previous period) is due to the counteracting effect of some of the factors that shape the gap, many of which notably changed their impact direction with respect to the previous period. Hence, by contrast to the expansionary phase, the relative endowments of immigrants' observed characteristics tended to improve, especially as regards the type of jobs they hold (changes in occupation and jobs with supervisory tasks explain jointly $-0.015 \log$ points of the increase in the gap in the last two models ${ }^{10}$ and their educational level. Additionally, changes in the effect of unobserved factors were also favourable for immigrant relative wages $(-0.016 \log$ points). Yet, the effect of both factors was offset by those derived from changes in the returns of the observed characteristics (0.006 log points) and, especially, from the sharp intensification of the segregation of immigrants into low-wage firms (0.041 log points). Results from model 2 show, in turn, that the latter factor was partially due to the reallocation of immigrants to low-wage sectors and to firms without collective agreements (both factors explain jointly $0.018 \log$ points).

\section{[Table 3 about here]}

Figures 2, 3 and 4 attend to the differences between natives and immigrants in the quantiles of the log hourly wages distribution and show the results of the decomposition obtained via the methodology proposed by Fortin, Lemieux and Firpo (2011). This evidence has been obtained using as explanatory variables sociodemographic characteristics of individuals (thus, following model 1) and also jobs and firms attributes (model 2). Figures 2 and 3 distinguish only between the aggregate contribution of characteristics and returns components, whereas Figure 4 contains the detailed results of the individual effects of explanatory variables through the former component in the case of model 2 (with the aim of facilitating the presentation, explanatory variables have been grouped into three categories, depending if they are individual characteristics of the workers, attributes of the jobs or characteristics of the firms). Additional information on the results of the decomposition can be found in Tables 4 and 5 .

[Tables 4 and 5 about here]

Aggregate results with model 1 (Figure 2) suggest that the increasing profile of the nativeimmigrant gap along the wage distribution is explained by the increasing profile of both the characteristics and returns component and that, as in the case of the previous decomposition of the difference in average wages, both components tend to explain alike the gap in different parts

\footnotetext{
10 This finding is consistent with the fact that the deep destruction of employment in Spain after the onset of the Great Recession has affected especially low-quality jobs (OECD, 2010, 2013b) and immigrants (OECD, 2013a).
} 
of the distribution. However, according to evidence obtained with the model 2, the nativeimmigrant wage gap throughout the wage distribution tends to be explained basically by differences in the endowments of characteristics (Figure 3). Consequently, the returns component has in general a negligible contribution to the gap, with the only exception of some influence in the right part of the distribution. Moreover, according to the detailed results of the decomposition, the bulk of the gap is actually explained by differences in the characteristics of the jobs hold by natives and immigrants (Figure 4) and, particularly, by the lower tenure of immigrants, their presence in low-wage occupations and, to a lesser extent, in jobs without supervisory tasks (Table 5). It should be noted that this overall evidence is generally consistent with that obtained previously regarding the decomposition of the difference in the average wages of native and immigrant workers (Table 2).

With regards to changes over time, the increase of the gap between 2002 and 2006 which occurs mainly in the upper part of the wage distribution is mainly explained by the increase in the magnitude of the characteristics component in the right part of that distribution (Figure 3). This upsurge is explained, in turn, by an intensification of the differences in natives and immigrants' endowments of jobs characteristics in favour of the former (Figure 4), especially regarding tenure, occupation and supervision (Table 5). On the other hand, the changes of the gap observed in the period 2006-2010 (namely, a rise in the lower part of the distribution and a decrease in the right tail) are essentially explained by a change in the profile of the characteristics components, whereby differences in the endowments of characteristics in favour of native workers become more important in the left part of the distribution and, by contrast, less intense in the upper tail (Figure 3). Again, these modifications are driven by changes in the endowments of job characteristics with a prominent role of occupation and supervision (Figure 4 and Table 5).

[Figures 2, 3 and 4 about here]

\section{Conclusions}

The aim of this article is to examine relative wages of immigrants in Spain, with a particular focus on the impact of the Great Recession. As usual in most previous studies focusing on the relative treatment of immigrants in the labour market the empirical analysis is restricted to men. The study is based on matched employer-employee microdata from the Encuesta de Estructura Salarial, a survey conducted in Spain with a harmonized methodology common to other members of the European Union, and on two different econometric decomposition techniques. The first one is an extension of the methodology of Juhn, Murphy and Pierce (1991, 1993) adapted for its use with matched employer-employee microdata which permits, inter alia, to observe the impact of firm segregation on the native-immigrant average wage gap and its evolution over time. The 
second technique is the methodology proposed by Fortin, Lemieux and Firpo (2011) which allows the development of a detailed decomposition of wage differences across the entire wage distribution.

The obtained results confirm that immigrant men suffer a significant wage disadvantage in the Spanish labour market compared with native men and that this disadvantage increases along the wage distribution. Moreover, although this wage gap shows an upward trend over the overall examined period, the upsurge is much more significant during the economic expansion than after the onset of the Great Recession. Descriptive evidence also shows that Spaniards and immigrant men differ significantly in their relative observed sociodemographic characteristics and that immigrants relative characteristics are generally associated to lower wages. Nonetheless, whereas immigrants' disadvantages in the endowments of characteristics increased in general during the economic expansion, they tended to decrease in some dimensions during the economic downturn and the consequent employment destruction that affected especially immigrants in low-skilled jobs. More generally speaking, it is possible that the degree of selection of immigrants would have played a role, as available evidence concludes that immigrant flows to Spain became more positively selected after the onset of the Great Recession (Fernández-Huertas, 2014). In particular, it seems that after the onset of the crisis immigrants in Spain tend to show better productive characteristics endowments (especially in terms of education and age), which is in line with the descriptive statistics provided in our study. On the other hand, available evidence suggests that the participation rate of immigrant men in Spain does not tend to respond to cyclical conditions and that the relevant impacts of the economic crisis on migration inflows and outflows in Spain occurred in the final years of the crisis, after the period examined in the article. As a consequence, the effect of potential selection of immigrants into the workforce related to unobservable factors derived from the crisis could plausibly not affect the results provided in our research.

The results of the decomposition of wage differentials show that differences in the endowments of observed characteristics explain the bulk of the native-immigrant wage gap in Spain each of the years considered, both in terms of average wages and of the differentials observed along the wage distribution, and that differences in location across type of jobs seem to be especially important. Thus, the predominant presence of immigrants in low-wage occupations as well as their relatively lower endowments of tenure particularly hit their relative wages, being the segregation of immigrants into low-wage firms also a factor with a quite significant influence on the wage differential. These findings are in line with results of previous studies for other economies in that the segregation of immigrants into low-wage labour market segments is a key explanatory element of their lower relative wages. Yet, it is noteworthy that estimated intra-firm wage differentials are almost negligible, which confirms that, once differences in individual, jobs 
and firms observed characteristics are accounted for, in the case of the Spanish labour market immigrants receive in general a similar wage treatment than natives.

On the other hand, the Great Recession has had a remarkable impact on the relative wages of immigrants in Spain, given that the significant increase of the native-immigrant wage gap observed during the expansionary period slowed during the economic downturn. Our findings suggest that the substantial increase of the gap during the expansionary period was due to the worsening of the relative endowments of the observed characteristics of immigrants, with a prominent role of the intensification of their occupational and firm segregation. Conversely, the slight increase of the native-immigrant wage gap after the onset of the economic recession is explained by the fact that the perjudicial effect on wages of the hard intensification of the segregation of immigrants into low-wage firms was partly counteracted by the positive impact of immigrants' relative characteristics improvement derived from the intense employment destruction that affected mostly to low-skilled immigrants. Thus our results confirm that, as suggested by previous studies, changes in the economic cycle could become an important driver in determining native-immigrant wage differentials and its evolution over time and that, in the case of Spain, the effects of this factor operate essentially via composition effects associated to the characteristics of employment creation and destruction during expansionary phases and downturns, respectively. 


\section{References}

Adsera, A. and Chiswich, B.R. (2007): "Are there gender and country of origin differences in immigrant labor market outcomes across European destinations?", Journal of Population Economics, Vol. 20, pp. 495-526.

Aeberhardt, R. and Pouget, J. (2010): "National origin differences in wages and hierarchical positions", Annals of Economics and Statistics, No 99/100, pp. 117.139.

Alcobendas, M.A. and Rodríguez-Planas, N. (2009): "Immigrant assimilation process in a segmented labor market", IZA Discussion Paper No 4394.

Alonso-Villar, O. and del Río, C. (2013): "Occupational segregation in a country of recent mass immigration: Evidence from Spain”, Annals of Regional Science, Vol. 50 (1), pp. 109-134.

Amuedo-Dorantes and de la Rica, S. (2007): "Labor market assimilation of recent immigrants in Spain", British Journal of Industrial Relations, Vol. 45(2), pp. 257-284.

Amuedo-Dorantes, C. and de la Rica, S. (2011): "Complements or substitutes? Task specialization by gender and nativity in Spain”, Labour Economics, Vol. 18, pp. 697-707.

Amuedo-Dorantes, C.; Malo, M. A.; Muñoz-Bullón, F. (2013): "New evidence on the impact of legal status on immigrant labor market performance: The Spanish case", Labour, 27(1), pp. 93-113.

Ashenfelter, O. (1970): "Changes in labor market discrimination over time", Journal of Human Resources, Vol. 5 (4), pp. 403-430.

Aslund, O. and Skans, O.N. (2010): "Will I see you at work? Ethnic workplace segregation in Sweeden, 1985-2002", Industrial and Labor Relations Review, Vol. 63 (3), pp. 471-493.

Aydemir, A. (2003): "Effects of the business cycle on the labour market assimilation of immigrants", in Beach, C., Green, A. and Reitz, J. (eds.): Canadian Immigration Policy for the 21st Century, Montreal and Kingston: McGill-Queen's University Press, pp. 372-412.

Aydemir, A. and Skuterud, M. (2008): "The immigrant wage differential within and across establishments", Industrial and Labor Relations Review, Vol. 61 (3), pp. 334-352.

Baker, M. and Benjamin, D. (1994): "The performance of immigrants in the Canadian labor market", Journal of Labor Economics, Vol. 12(3), pp. 369-405.

Barrett, A., McGuinness, S. and O'Brien, M. (2012): "The immigrant earnings disadvantage across the earnings and skills distributions: The case of immigrants from the EU's New Member States", Industrial and Labor Relations Review, Vol. 50 (3), pp. 475-481.

Barth, E., Bratsberg, B. and Raaum, O. (2004): "Identifying earnings assimilation of immigrants under changing macroeconomic conditions", Scandinavian Journal of Economics, Vol. 106(1), pp. 1-22.

Barth, E., Bratsberg, B. and Raaum, O. (2006): "Local unemployment and the relative wages of immigrants: evidence from current population surveys", Review of Economics and Statistics, Vol. 88(2), pp. 243-263.

Barth, E., Bratsberg, B. and Raaum, O. (2012): "Immigrant wage profiles within and between establishments", Labour Economics, Vol. 19 (4), pp. 541-556.

Bayard, K., Hellerstein, J., Neumark, D. and Troske, K. (1999): "Why Are Racial and Ethnic Wage Gaps Larger for Men than for Women? Exploring the Role of Segregation Using the New WorkerEstablishment Characteristics Database", in Haltiwanger, J.C., Lane, J.I., Spletzer, J.R., Theeuwes, J.J. and Troske, K.eds., The Creation and Analysis of Employer-Employee Matched Data (Amsterdam: Elsevier Science B.V.), pp. 175-203.

Becker, G. (1957): The economics of discrimination, Chicago: University of Chicago Press.

Bentolila, S., Cahuc, P., Dolado, J.J. and Le Barbanchon, T. (2012): "Two-tier labour markets in the Great Recession: France Versus Spain", The Economic Journal, Vol. 122 (562), pp. F155-F187.

Bernardi, F., Garrido, L. and Miyar, M. (2011): "The recent fast upsurge of immigrants in Spain and their employment patterns and occupational attainment", International Migration, Vol. 49 (1), pp.148-187.

Biddle, J. and Hamermesh, D. (2013): "Wage discrimination over the business cycle", IZ A Journal of Labour Policy, Vol. 2 (7).

Blau, F.D. and Kahn, L.M. (1992) 'The Gender Earnings Gap: Learning from International Comparisons', American Economic Review, vol. 82, pp. 533-38.

Borjas, G.J. (1985): "Assimilation, changes in cohort quality, and the earnings of immigrants", Journal of Labor Economics, Vol. 3(4), pp. 463-489.

Borjas, G.J. (1994): “The economics of immigration", Journal of Economic Literature, Vol. 32 (4), pp. $1667-$ 1717(4).

Borjas, G.J. (1999): The economic analysis of immigration. In O. Ashenfelter and D. Card (eds.), Handbook of Labor Economics, Vol. 3 (A), Amsterdam: North-Holland, pp.1697-1760. 
Butcher, K.F. and DiNardo, J. (2002): "The immigrant and native-born wage distributions: Evidence from United States censuses", Industrial and labor relations review, Vol. 56(1), pp. 97-121.

Card, D. (2007): "How Immigration Affects U.S. Cities", CReAM Discussion Paper, no. 11/07, University College London.Card, D. and de la Rica, S. (2006): "Firm-level Contracting and the Structure of Wages", Industrial and Labor Relations Review, 59(4), pp. 573-593.

Carliner, G. (1980): "Wages, earnings and hours of first, second and third generation American males", Economic Inquiry, Vol. 18 (1), pp.87-102.

Carneiro, A., Fortuna, N. and Varejao, J. (2012): "Immigrants at new destinations: How they fare and why", Journal of Population Economics, Vol. 25 (3), pp. 1165-1185.

Carrasco, R., Jimeno, J.F. and Ortega, C. (2008): "The effect of immigration on the labor market performance of native-born workers: some evidence for Spain", Journal of Population Economics, Vol. 21, pp. 627-648.

Carrasco, R., Jimeno, J.F. and Ortega, C. (2014): "Returns to Skill and the Distribution of Wages: Spain 1995-2006", Oxford Bulletin of Economics and Statistics, doi: 10.1111/obes.12077.

Chiswick, B.R. (1978): "The effect of Americanization on the earnings of foreign-born men", Joumal of Political Economy, Vol. 86 (5), pp. 897-922.

Chiswick, B., Cohen, Y. and Zach, T. (1997): "The labor market status of immigrants: Effects of the unemployment rate at the arrival and duration of residence", Industrial and Labor Relations Review, Vol. 50(2), pp. 289-303.

Chiswick, B., Lee, Y., and Miller, P. (2005): “A Longitudinal Analysis of Immigrant Occupational Mobility: A Test of the Immigrant Assimilation Hypothesis", International Migration Review, Vol. 39 (2), pp. 332353.

Chiswick, B.R.; Anh, T.L.; Miller, P.W. (2008): "How immigrants fare across the earnings distribution in Australia and the United States", Industrial and Labor Relations Review, Vol. 61(3), pp. 353-373.

Constant, A.F. and Massey, D.S. (2003): "Self-selection, earnings and out-migration: A longitudinal study of immigrants to Germany", Journal of Population Economics, Vol. 16 (4), pp. 631-653.

Constant, A.F and Zimmermann, K.F. (2013): "Migration and ethnicity: an introduction", in International Handbook on the Economics of Migration, Edwar Elgan, Cheltenham, UK.

D'Amuri, Francesco, Gianmarco Ottaviano, and Giovanni Peri (2010): "The Labor Market Impact of Immigration in Western Germany in the 1990s.", European Economic Review, Vol. 54, pp. 550-570.

Davia, M. A. y Hernanz, V. (2002): "Temporary Employment and Segmentation in the Spanish Labour Market: An Empirical Analysis through the Study of Wage Differentials", Spanish Economic Review, 6, pp. 291-318.

De la Rica, S., Glitz, A. and Ortega, A. (2014): 'Immigration in Spain: What have we learned from recent evidence?', Cuadernos económicos de ICE, $\mathrm{N}^{\circ} 87$

De la Rica, S. and Polonyankina, T. (2014): "The impact of immigration on occupational specialization among natives in Spain: Does the business cycle matter?", Revista de Economía Aplicada, XXI (63), pp. 51-75.

DiNardo, Fortin, N.M. and Lemieux, T. (1996): "Labor market institutions and the distribution of wages, 1973-1992: A semi-parametric approach", Econometrica, Vol. 64 (5), pp. 1011-1044.Dowhan, D.J. and Duleep, H.O. (2002): "Insights form longitudinal data on earnings of US foreign born men", Demography, Vol. 39 (3), pp. 485-506.

Dustmann, C., Glitz A. and Voguel, T. (2010): "Employment, wages, and the economic cycle: Differences between immigrants and natives", European Economic Review, Vol. 54(1), pp. 1-17.

Ellis, M., Wright, R. and Parks, V. (2014): "Work together, live apart? Geographies of racial and ethnic segregation at home and at work", Annals of the Association of American Geographers, Vol. 94, pp. 620-637.

European Commission (2013): Labour market developments in Europe, 2013. European economy 2/2011. European Commission, Luxembourg.

Fernández, C. and Ortega, C. (2008): "Labor market assimilation of immigrants in Spain: employment at the expense of bad job-matches?”, Spanish Economic Review, Vol. 10 (2) , pp. 83-107.

Fernández-Huertas Moraga, J. (2014): Immigrant selection over the business cycle: The Spanish boom at the Great Recession", Cuadernos Económicos del ICE, 87, 57-84.

Firpo, S.; Fortin, N., \& Lemieux, T. (2009). Unconditional Quantile Regressions. Econometrica, 77(3), 953973.

Fortin, N.; Lemieux, T.; Firpo, S.; (2011): "Decomposition Methods in Economics", Handbook of Labor Economics, Vol. 4, Chapter 1, pp. 1-102. Elsevier. 
Friedberg, R. M. (2000): "You can't take it with you? Immigrant assimilation and the portability of human capital", Journal of Labour Economics, Vol. (18), pp. 221-251.

García-Pérez, J.I., Muñoz-Bullón, F. and Prieto-Rodríguez, M. (2012): “The wage gap between foreign and Spanish nationals in Spain: an analysis using matched employer-employee data", International Migration. doi: 10.1111/imig.12000

Gartner, H. and Stephan, G. (2004) 'How collective contracts and works councils reduce the gender wage gap', IAB Discussion paper $7 / 2004$.

González, L. and Ortega, F. (2011):“How do very open economies adjust to large immigration flows? Evidence from Spanish regions", Labour Economics 18(1): 57-70.

Groshen, E.L.( 1991): "Five Reasons Why Wages Vary Among Employers", Industrial Relations, Vol. 30(3), pp. 350-381.Hellerstein, J.K., McInerney, M. and Numark, D. (2011): "Neighbors and coworkers: The importance of residential labor market networks", Journal of Labor Economics, Vol. 29, pp. 659-695.

Heckman, J. (1979): "Sample Selection Bias as a Specification Error", Econometrica, 47(1), pp. 153-161.

Honeys, H., Miller, D.L. and Schaller, J. (2012): "Who suffers during recessions?", Journal of Economic Perspectives, Vol. 26 (3), pp. 27-48.

Instituto Nacional de Estadística (2014): "Comparación de los ingresos del trabajo entre la Encuesta de Condiciones de Vida y las fuentes administrativas", mimeo.

Izquierdo, M., Lacuesta, A. and Vegas, R. (2009): "Assimilation of immigrants in Spain: A longitudinal analysis", Labour Economics, Vol. 16, pp. 669-678.

Izquierdo, M., Jimeno, J.F. and Lacuesta, A. (2015): “Spain: from immigration to emigration?”, Documento de Trabajo no 1503, Banco de España.

Johnston, D. and Lordan, G. (2014): "When work disappears: Racial prejudice and recession labour market penalties", CEP Discussion Paper No 1257.

Juhn, C., Murphy, K. and Pierce, B. (1991): "Accounting for the slowdown in black-white convergence", in M. Osters (eds.) Workers and Their Wages, 107-143. Washington DC: American Enterprise Institute Press.

Juhn, C., Murphy, K. and Pierce, B. (1993): "Wage inequality and the rise in returns to skills", Journal of Political Economy, Vol. 101, pp. 410-442.

Kaufman, R.L. (2010): Race, gender and the labor market: Inequalities at work, Lynne Rienner Publishers.

LaLonde, R.J. and Topel, R.H. (1991): Labor market adjustments to increased immigration, in Abowd, J.M. and Friedman, R.B., eds., Immigration, trade and the labor market, University of Chicago Press.

Lane, J. I., Salmon, L. A. and Spletzer, J. R. (2013): Establishment wage differentials, ed. US Bureau of Labor Statistics.

Larramona, G. (2013): “Out-migration of Spanish immigrants”, Population, Vol. 68 (2), pp. 213-236.

Machado, J. and Mata, J.A.F. (2005): "Counterfactual decomposition of changes in wage distributions using quantile regression", Journal of Applied Econometrics, Vol. 20 (4), pp. 445-465.

Manacorda, M. Manning, A. and Wadsworth, J. (2012): "The impact of immigration on the structure of male wages: theory and evidence from Britain", Journal of the European Economic Association, Vol. 10, pp. 120-151.

Melly, B. (2005): "Decomposition of differences in distribution using quantile regression", Labour Economics, Elsevier, 12 (4): 577-590.

Melly, B. (2006): "Estimation of counterfactual distributions using quantile regression", mimeo, Swiss Institute for International Economics and Applied Economic Research, University of St. Gallen.

Montero, J. M. and Regil, A. V. (2015): "La resistencia cíclica y los factores determinantes de la tasa de actividad en España", Boletín económico, Banco de España, Mayo.

Motellón, E. and López-Bazo, E. (2015): "Job loss among immigrant and native workers: Evidence from Spain's economic downturn”, Social Indicator Research, Vol. 120 (2), pp. 345-371.

Nanos, P. and Schluter, C. (2014): "The composition of wage differentials between migrants and natives", European Economic Review, Vol. 65, pp. 23-44.

Neumark, D. (1988) 'Employer's discriminatory behaviour and the estimation of wage discrimination', Journal of Human Resources, Vol. 23, pp. 279-295.

Nicodemo, C. and Ramos, R. (2012): "Wage differentials between native and immigrant women in Spain. Accounting for differences in support", International Journal of Manpower, Vol. 33(1), pp. 118-136.

Ñopo, H. (2008): "Matching as a Tool to Decompose Wage Gaps", The Review of Economics and Statistics, 90 (2), pp. 290-299.

Orrenius, P.M. and Zavodny, M. (2010): "Mexican immigrant employment outcomes over the business cycle", American Economic Review, Vol. 100(2), pp. 316-20. 
Ottaviano, G. and Peri, G. (2012): "Rethinking the effect of immigration on wages", Journal of the European Economic Association, Vol. 10, pp. 152-197.

Oaxaca, R. and Ransom, M. (1994) 'On discrimination and the decomposition of wage differentials', Journal of Econometrics, Vol. 61, pp. 5-22.

OECD (2010): Employment Outlook, Moving beyond the jobs crisis. OECD Paris.

OECD (2013a): International Migration Outlook, DOI: 10.1787/migr outlook-2013-en.

OECD (2013b): Employment Outlook, All in all together? The experience of different labour market groups following the crisis, http://dx.doi.org/10.1787/empl outlook-2013-en.

Phelps, E.S. (1972): "A statistical theory of racism and sexism", American Economic Review, Vol. 62, pp. 659661.

Raphael, S. and Smolensky, E. (2009): "Immigration and poverty in the United States", American Economic Review, Vol. 99 (2), pp.41-44.

Ruist, J. (2013): "Immigrant-native wage gaps in time series: complementarities or composition effects?", Economics Letters, Vol. 119, pp. 154-156.

Simón, H. (2010): "International Differences in Wage Inequality: A New Glance with European Matched Employer-Employee Data", British Journal of Industrial Relations, Vol. 48(2), pp. 310-346.

Simón, H., Sanromá, E. and Ramos, R. (2008): "Labour segregation and immigrant and native-born wage distributions in Spain: an analysis using matched employer-employee data", Spanish Economic Review, Vol. 10 (2), pp. 135-168.

Simón, H., Ramos, R. and Sanromá, E. (2014): "Immigrant Occupational Mobility: Evidence from Spain", European Journal of Population, Vol.30 (2), pp. 223-255.

Strömgern M., Tammaru, T., Danzer, A., van Ham, M., Marcinczak, S., Stjernström, O. and Lindgren, U. (2014): "Factors shaping workplace segregation betwwen natives and immigrants", Demography, Vol. 51, pp. 645-671.

United Nations, Department of Economics and Social Affairs, Population Division (2009): "International Migration Report 2006: a global assessment", United Nations, New York: http://www.un.org/esa/population/unpop.htm

Yoshida, Y. and Smith, M.R. (2005): "Training and the earnings of immigrant males: Evidence from the Canadian Workplace and Employee Survey", Social Science Quarterly, Vol. 86, pp. 1218-1241. 
Table 1.

Wage differentials between native and immigrant men in Spain.

\begin{tabular}{cccccc}
\hline & 2002 & 2006 & 2010 & $\begin{array}{c}\text { Change } \\
2002-2006\end{array}$ & $\begin{array}{c}\text { Change } \\
2006-2010\end{array}$ \\
\hline $\begin{array}{l}\text { Average } \\
\text { Percentiles }\end{array}$ & $0.204^{* * *}$ & $0.244^{* * *}$ & $0.259^{* * *}$ & $0.040^{* * *}$ & $0.015^{* * *}$ \\
10 & $0.078^{* * *}$ & $0.078^{* * *}$ & $0.145^{* * *}$ & $-0.001^{* * *}$ & $0.067^{* * *}$ \\
20 & $0.097^{* * *}$ & $0.100^{* * *}$ & $0.168^{* * *}$ & $0.022^{* * *}$ & $0.068^{* * *}$ \\
30 & $0.120^{* * *}$ & $0.128^{* * *}$ & $0.211^{* * *}$ & $0.031^{* * *}$ & $0.083^{* * *}$ \\
40 & $0.157^{* * *}$ & $0.168^{* * *}$ & $0.253^{* * *}$ & $0.048^{* * *}$ & $0.085^{* * *}$ \\
50 & $0.208^{* * *}$ & $0.222^{* * *}$ & $0.303^{* * *}$ & $0.065^{* * *}$ & $0.081^{* * *}$ \\
60 & $0.270^{* * *}$ & $0.296^{* * *}$ & $0.345^{* * *}$ & $0.088^{* * *}$ & $0.049^{* * *}$ \\
70 & $0.321^{* * *}$ & $0.365^{* * *}$ & $0.369^{* * *}$ & $0.095^{* * *}$ & $0.004^{* * *}$ \\
80 & $0.368^{* * *}$ & $0.422^{* * *}$ & $0.368^{* * *}$ & $0.101^{* * *}$ & $-0.054^{* * *}$ \\
90 & $0.344^{* * *}$ & $0.440^{* * *}$ & $0.320^{* * *}$ & $0.072^{* * *}$ & $-0.120^{* * *}$ \\
\hline
\end{tabular}

Notes: The wage gap corresponds to the differential of the logarithm of the hourly wage.

$* p<0.1 ; * * p<0.05 ; * * * p<0.01$. 
Table 2.

Decomposition of the differential in average wages between native and immigrant men. Juhn-Murphy-Pierce decomposition.

\begin{tabular}{|c|c|c|c|c|c|c|c|c|c|}
\hline & \multicolumn{3}{|c|}{2002} & \multicolumn{3}{|c|}{2006} & \multicolumn{3}{|c|}{2010} \\
\hline & Model 1 & Model 2 & Model 3 & Model 1 & Model 2 & Model 3 & Model 1 & Model 2 & Model 3 \\
\hline Wage differential & $0.204 * * *$ & $0.204 * * *$ & $0.204 * * *$ & $0.244^{* * *}$ & $0.244^{* * *}$ & $0.244^{* * *}$ & $0.259^{* * *}$ & $0.259^{* * *}$ & $0.259^{* * *}$ \\
\hline Characteristics (1) & $0.112 * * *(54.9)$ & $0.200 * * *(98.0)$ & $0.167 * * *(81.9)$ & $0.120^{* * *}(49.2)$ & $0.226^{* * *}(92.6)$ & $0.182 * * *(74.6)$ & $0.114 * * *(44.0)$ & $0.241 * * *(93.1)$ & $0.171 * * *(66.0)$ \\
\hline Educational attainment & 0.064 & 0.013 & 0.010 & 0.079 & 0.022 & 0.013 & 0.059 & 0.019 & 0.013 \\
\hline Age & 0.048 & 0.015 & 0.014 & 0.041 & 0.010 & 0.011 & 0.055 & 0.016 & 0.015 \\
\hline Tenure & - & 0.076 & 0.066 & - & 0.090 & 0.066 & - & 0.095 & 0.072 \\
\hline Type of contract & - & 0.014 & 0.014 & - & 0.004 & 0.009 & - & -0.001 & 0.001 \\
\hline Full- or part-time & - & 0.000 & 0.000 & - & 0.000 & 0.000 & - & 0.002 & -0.001 \\
\hline Occupation & - & 0.064 & 0.044 & - & 0.074 & 0.053 & - & 0.068 & 0.048 \\
\hline Supervisory tasks & - & 0.015 & 0.019 & - & 0.021 & 0.030 & - & 0.015 & 0.023 \\
\hline Region & - & -0.014 & - & - & -0.009 & - & - & -0.012 & - \\
\hline Activity sector & - & -0.005 & - & - & -0.010 & - & - & 0.007 & - \\
\hline Firm size & - & 0.013 & - & - & 0.018 & - & - & 0.019 & - \\
\hline Collective agreement & - & 0.009 & - & - & 0.006 & - & - & 0.013 & - \\
\hline Wage residuals (2) & $0.092^{* * *}(45.1)$ & $0.004(2.0)$ & $-0.003(-0.1)$ & $0.124 * * *(50.8)$ & $0.018^{* *}(7.4)$ & $0.009 *(3.7)$ & $0.145^{* * *}(56.0)$ & $0.018^{* *}(6.9)$ & $-0.007(-2.7)$ \\
\hline Firm fixed effects (3) & - & - & $0.040 * * *(19.6)$ & - & - & $0.053^{* * *}(21.7)$ & - & - & $0.095^{* * *}(36.7)$ \\
\hline
\end{tabular}

Notes: The table shows the results obtained after applying equation (3) to the different waves of the Encuesta de Estructura Salarial. Model 1 corresponds to a specification of the wage equation that includes individual

characteristics (age and education); model 2 incorporates to the specification attributes of jobs and firms (tenure, type of contract, full- or part-time, supervisory tasks, occupation, region, sector, size and type of collective agreement), whereas model 3 includes individual and job attributes and firm fixed effects instead of firm attributes. The percentage of the wage differential explained by each term appears in brackets.

${ }^{*} p<0.1$; ** $p<0.05$; *** $p<0.01$ 
Table 3.

Decomposition of the change in the differential in average wages between native and immigrant men. Juhn-Murphy-Pierce decomposition.

\begin{tabular}{|c|c|c|c|c|c|c|}
\hline & & & $2002-2006$ & & & $2006-2010$ \\
\hline Wage differential $_{B}$-Wage differential ${ }_{A}$ & $0.040^{* * *}$ & $0.040^{* * *}$ & $0.040^{* * *}$ & $0.015^{* * *}$ & $0.015^{* * *}$ & $0.015^{* * *}$ \\
\hline Characteristics (1) & $0.021 * * *(52.5)$ & $0.035^{* * *}(87.5)$ & $0.027 * * *(67.5)$ & $-0.020^{* * *}(-133.3)$ & $0.000(0.0)$ & $-0.017 * * *(-113.3)$ \\
\hline Age & 0.000 & 0.000 & 0.000 & 0.006 & 0.002 & 0.002 \\
\hline Tenure & - & 0.003 & 0.002 & - & 0.006 & 0.004 \\
\hline Type of contract & - & 0.000 & 0.000 & - & 0.001 & -0.001 \\
\hline Region & - & 0.006 & - & - & -0.004 & - \\
\hline Activity sector & - & -0.008 & - & - & 0.011 & - \\
\hline Firm size & - & 0.005 & - & - & 0.001 & - \\
\hline Collective agreement & - & 0.000 & - & - & 0.007 & - \\
\hline Returns (2) & $-0.012 * * *(-30.0)$ & $-0.009 * *(-22.5)$ & $-0.012 * * *(-30.0)$ & $0.014 * * *(93.3)$ & $0.014 * * *(93.3)$ & $0.006(40.0)$ \\
\hline Educational attainment & -0.006 & 0.004 & 0.000 & 0.006 & 0.006 & 0.005 \\
\hline Supervisory tasks & - & 0.002 & 0.005 & - & -0.001 & 0.001 \\
\hline Region & - & -0.001 & - & - & 0.000 & - \\
\hline Activity sector & - & 0.002 & - & - & 0.007 & - \\
\hline Firm size & - & 0.001 & - & - & 0.000 & - \\
\hline Collective agreement & - & -0.003 & - & - & 0.000 & - \\
\hline Relative wage residuals (3) & $0.030^{* * *}(75.0)$ & $0.014 * * *(35.0)$ & $0.011 * * *(27.5)$ & $0.019 * * *(126.6)$ & $0.001(6.7)$ & $-0.016^{* * *}(-106.7)$ \\
\hline Residual wage dispersion (4) & $0.001(2.5)$ & $0.000(0.0)$ & $0.000(0.0)$ & $0.002(13.3)$ & $0.000(0.0)$ & $0.000(0.0)$ \\
\hline Relative firm fixed effects (5) & - & - & $0.014 * * *(35.0)$ & - & - & $0.041 * * *(273.3)$ \\
\hline Firm fixed effects dispersion (6) & - & - & $0.000(0.0)$ & - & - & $0.000(0.0)$ \\
\hline
\end{tabular}


Table 4.

Decomposition of wage differentials between native and immigrant men. Fortin-Lemieux-Firpo decomposition. Model 1.

\begin{tabular}{|c|c|c|c|c|c|c|c|c|c|c|}
\hline & & \multicolumn{3}{|c|}{2002} & \multicolumn{3}{|c|}{2006} & \multicolumn{3}{|c|}{2010} \\
\hline & & 10th perc. & Median & 90th perc. & 10th perc. & Median & 90th perc. & 10th perc. & Median & 90th perc. \\
\hline \multirow[t]{9}{*}{ Total } & Native men & $\begin{array}{l}1.545 \\
(0.002)^{* * *}\end{array}$ & $\begin{array}{l}1.977 \\
(0.002)^{* * *}\end{array}$ & $\begin{array}{l}2.749 \\
(0.004)^{* * *}\end{array}$ & $\begin{array}{l}1.713 \\
(0.002)^{* * *}\end{array}$ & $\begin{array}{l}2.145 \\
(0.002)^{* * *}\end{array}$ & $\begin{array}{l}2.900 \\
(0.004)^{* * *}\end{array}$ & $\begin{array}{l}1.872 \\
(0.002)^{* * *}\end{array}$ & $\begin{array}{l}2.373 \\
(0.002)^{* * *}\end{array}$ & $\begin{array}{l}3.102 \\
(0.004) * * *\end{array}$ \\
\hline & Immigrant men & 1.468 & 1.769 & 2.405 & 1.635 & 1.923 & 2.460 & 1.727 & 2.070 & 2.782 \\
\hline & & $(0.007)^{* * *}$ & $(0.007)^{* * *}$ & $(0.025)^{* * *}$ & $(0.005)^{* * *}$ & $(0.004)^{* * *}$ & $(0.014)^{* * *}$ & $(0.006)^{* * *}$ & $(0.005)^{* * *}$ & $(0.018) * * *$ \\
\hline & Difference & 0.077 & 0.208 & 0.344 & 0.078 & 0.222 & 0.440 & 0.145 & 0.303 & 0.320 \\
\hline & & $(0.007) * * *$ & $(0.007)^{* * *}$ & $(0.026) * * *$ & $(0.005) * * *$ & $(0.004)^{* * *}$ & $(0.014)^{* * *}$ & $(0.006) * * *$ & $(0.005) * * *$ & $(0.018)^{* * *}$ \\
\hline & Characteristics & 0.036 & 0.119 & 0.188 & 0.036 & 0.120 & 0.200 & 0.049 & 0.118 & 0.189 \\
\hline & & $(0.002)^{* * *}$ & $(0.005)^{* * *}$ & $(0.008)^{* * *}$ & $(0.002)^{* * *}$ & $(0.003)^{* * *}$ & $(0.005)^{* * *}$ & $(0.002)^{* * *}$ & $(0.003)^{* * *}$ & $(0.006) * * *$ \\
\hline & Coefficients & 0.041 & 0.089 & 0.156 & 0.042 & 0.101 & 0.240 & 0.096 & 0.185 & 0.131 \\
\hline & & $(0.008)^{* * *}$ & $(0.008)^{* * *}$ & $(0.023)^{* * *}$ & $(0.005)^{* * *}$ & $(0.005)^{* * *}$ & $(0.013)^{* * *}$ & $(0.006)^{* * *}$ & $(0.006)^{* * *}$ & $(0.017)^{* * *}$ \\
\hline \multirow[t]{4}{*}{ Characteristics } & Age & 0.020 & 0.054 & 0.076 & 0.016 & 0.044 & 0.068 & 0.025 & 0.057 & 0.091 \\
\hline & & $(0.001)^{* * *}$ & $(0.003)^{* * *}$ & $(0.004)^{* * *}$ & $(0.001)^{* * *}$ & $(0.002)^{* * *}$ & $(0.003)^{* * *}$ & $(0.001)^{* * *}$ & $(0.002)^{* * *}$ & $(0.003)^{* * *}$ \\
\hline & Education & 0.016 & 0.065 & 0.111 & 0.020 & 0.077 & 0.132 & 0.024 & 0.061 & 0.098 \\
\hline & & $(0.001)^{* * *}$ & $(0.004)^{* * *}$ & $(0.007)^{* * *}$ & $(0.001)^{* * *}$ & $(0.002)^{* * *}$ & $(0.004)^{* * *}$ & $(0.001)^{* * *}$ & $(0.003)^{* * *}$ & $(0.005)^{* * *}$ \\
\hline$N$ & & 78,424 & 78,424 & 78,424 & 82,195 & 82,195 & 82,195 & 78,424 & 78,424 & 78,424 \\
\hline
\end{tabular}


Table 5.

Decomposition of wage differentials between native and immigrant men. Fortin-Lemieux-Firpo decomposition. Model 2.

\begin{tabular}{|c|c|c|c|c|c|c|c|c|c|c|}
\hline & & \multicolumn{3}{|c|}{2002} & \multicolumn{3}{|c|}{2006} & \multicolumn{3}{|c|}{2010} \\
\hline & & 10th perc. & Median & 90th perc. & 10th perc. & Median & 90th perc. & 10th perc. & Median & 90th perc. \\
\hline \multirow[t]{9}{*}{ Total } & Native men & $\begin{array}{l}1.545 \\
(0.002)^{* * *}\end{array}$ & $\begin{array}{l}1.977 \\
(0.002) * * *\end{array}$ & $\begin{array}{l}2.749 \\
(0.004)^{* * *}\end{array}$ & $\begin{array}{l}1.713 \\
(0.002)^{* * *}\end{array}$ & $\begin{array}{l}2.145 \\
(0.002) * * *\end{array}$ & $\begin{array}{l}2.900 \\
(0.004)^{* * *}\end{array}$ & $\begin{array}{l}1.872 \\
(0.002)^{* * *}\end{array}$ & $\begin{array}{l}2.373 \\
(0.002)^{* * *}\end{array}$ & $\begin{array}{l}3.102 \\
(0.004)^{* * *}\end{array}$ \\
\hline & Immigrant men & 1.468 & 1.769 & 2.405 & 1.635 & 1.923 & 2.460 & 1.727 & 2.070 & 2.782 \\
\hline & & $(0.007)^{* * *}$ & $(0.007) * * *$ & $(0.025)^{* * *}$ & $(0.005) * * *$ & $(0.004)^{* * *}$ & $(0.014)^{* * *}$ & $(0.006) * * *$ & $(0.005) * * *$ & $(0.018)^{* * *}$ \\
\hline & Difference & 0.077 & 0.208 & 0.344 & 0.078 & 0.222 & 0.440 & 0.145 & 0.303 & 0.320 \\
\hline & & $(0.007)^{* * *}$ & $(0.007)^{* * *}$ & $(0.026)^{* * *}$ & $(0.005)^{* * *}$ & $(0.004)^{* * *}$ & $(0.014)^{* * *}$ & $(0.006)^{* * *}$ & $(0.005)^{* * *}$ & $(0.018)^{* * *}$ \\
\hline & Characteristics & 0.076 & 0.223 & 0.272 & 0.081 & 0.255 & 0.340 & 0.139 & 0.270 & 0.310 \\
\hline & & $(0.003)^{* * *}$ & $(0.006) * * *$ & $(0.010)^{* * *}$ & $(0.003)^{* * *}$ & $(0.004) * * *$ & $(0.007)^{* * *}$ & $(0.003)^{* * *}$ & $(0.005)^{* * *}$ & $(0.008)^{* * *}$ \\
\hline & Coefficients & 0.001 & -0.015 & 0.072 & -0.003 & -0.034 & 0.100 & 0.006 & 0.033 & 0.010 \\
\hline & & $(0.008)$ & $(0.007)^{* *}$ & $(0.022)^{* * *}$ & $(0.006)$ & $(0.005)^{* * *}$ & $(0.013)^{* * *}$ & $(0.006)$ & $(0.005)^{* * *}$ & $(0.017)$ \\
\hline \multirow[t]{22}{*}{ Characteristics } & Age & 0.005 & 0.013 & 0.034 & 0.002 & 0.009 & 0.026 & 0.006 & 0.014 & 0.038 \\
\hline & & $(0.001)^{* * *}$ & $(0.001)^{* * *}$ & $(0.002)^{* * *}$ & $(0.001)^{* * *}$ & $(0.001)^{* * *}$ & $(0.002)^{* * *}$ & $(0.001)^{* * *}$ & $(0.001)^{* * *}$ & $(0.002)^{* * *}$ \\
\hline & Education & 0.004 & 0.012 & 0.021 & 0.007 & 0.019 & 0.033 & 0.011 & 0.021 & 0.030 \\
\hline & & $(0.001)^{* * *}$ & $(0.001)^{* * *}$ & $(0.002)^{* * *}$ & $(0.001)^{* * *}$ & $(0.001)^{* * *}$ & $(0.002)^{* * *}$ & $(0.001)^{* * *}$ & $(0.001)^{* * *}$ & $(0.002)^{* * *}$ \\
\hline & Tenure & 0.037 & 0.089 & 0.072 & 0.044 & 0.090 & 0.099 & 0.060 & 0.101 & 0.099 \\
\hline & & $(0.002)^{* * *}$ & $(0.002)^{* * *}$ & $(0.004)^{* * *}$ & $(0.002)^{* * *}$ & $(0.002)^{* * *}$ & $(0.004)^{* * *}$ & $(0.002)^{* * *}$ & $(0.002)^{* * *}$ & $(0.004)^{* * *}$ \\
\hline & Contract & 0.009 & 0.021 & 0.011 & 0.012 & 0.019 & -0.005 & 0.006 & 0.007 & -0.005 \\
\hline & & $(0.002)^{* * *}$ & $(0.002)^{* * *}$ & $(0.003)^{* * *}$ & $(0.002)^{* * *}$ & $(0.002)^{* * *}$ & $(0.003)^{*}$ & $(0.001)^{* * *}$ & $(0.001)^{* * *}$ & $(0.002)^{* * *}$ \\
\hline & Full-/part-time & 0.002 & -0.000 & -0.002 & 0.001 & 0.000 & -0.001 & 0.005 & 0.001 & -0.005 \\
\hline & & $(0.001)^{* * *}$ & $(0.000)$ & $(0.001)^{* * *}$ & $(0.000)^{*}$ & $(0.000)$ & $(0.000)^{*}$ & $(0.001)^{* * *}$ & $(0.000)^{* * *}$ & $(0.001)^{* * *}$ \\
\hline & Supervisory tasks & 0.005 & 0.015 & 0.021 & 0.006 & 0.024 & 0.033 & 0.005 & 0.016 & 0.023 \\
\hline & & $(0.000)^{* * *}$ & $(0.001)^{* * *}$ & $(0.002)^{* * *}$ & $(0.001)^{* * *}$ & $(0.001)^{* * *}$ & $(0.002)^{* * *}$ & $(0.000)^{* * *}$ & $(0.001)^{* * *}$ & $(0.002)^{* * *}$ \\
\hline & Occupation & 0.031 & 0.066 & 0.089 & 0.028 & 0.070 & 0.123 & 0.042 & 0.066 & 0.095 \\
\hline & & $(0.002)^{* * *}$ & $(0.003)^{* * *}$ & $(0.007)^{* * *}$ & $(0.002)^{* * *}$ & $(0.002)^{* * *}$ & $(0.004)^{* * *}$ & $(0.002)^{* * *}$ & $(0.002)^{* * *}$ & $(0.005)^{* * *}$ \\
\hline & Region & -0.014 & -0.024 & -0.017 & -0.009 & -0.013 & -0.009 & -0.006 & -0.013 & -0.015 \\
\hline & & $(0.001)^{* * *}$ & $(0.002)^{* * *}$ & $(0.002)^{* * *}$ & $(0.001)^{* * *}$ & $(0.002)^{* * *}$ & $(0.002)^{* * *}$ & $(0.001)^{* * *}$ & $(0.001)^{* * *}$ & $(0.002)^{* * *}$ \\
\hline & Sector & -0.012 & -0.000 & 0.017 & -0.022 & -0.001 & 0.012 & -0.003 & 0.009 & 0.021 \\
\hline & & $(0.001)^{* * *}$ & $(0.002)$ & $(0.003)^{* * *}$ & $(0.001)^{* * *}$ & $(0.001)$ & $(0.003)^{* * *}$ & $(0.001)^{* *}$ & $(0.001)^{* * *}$ & $(0.002)^{* * *}$ \\
\hline & Size & 0.007 & 0.019 & 0.016 & 0.011 & 0.031 & 0.022 & 0.016 & 0.027 & 0.018 \\
\hline & & $(0.001)^{* * *}$ & $(0.002)^{* * *}$ & $(0.002)^{* * *}$ & $(0.001)^{* * *}$ & $(0.002)^{* * *}$ & $(0.002)^{* * *}$ & $(0.001)^{* * *}$ & $(0.001)^{* * *}$ & $(0.001)^{* * *}$ \\
\hline & Collective agreement & 0.001 & 0.012 & 0.011 & -0.000 & 0.007 & 0.007 & -0.003 & 0.021 & 0.013 \\
\hline & & $(0.000)^{* * *}$ & $(0.001)^{* * *}$ & $(0.001)^{* * *}$ & $(0.000)$ & $(0.001) * * *$ & $(0.001)^{* * *}$ & $(0.001)^{* * *}$ & $(0.001)^{* * *}$ & $(0.001)^{* * *}$ \\
\hline$N$ & & 78,424 & 78,424 & 78,424 & 82,195 & 82,195 & 82,195 & 94,459 & 94,459 & 94,459 \\
\hline
\end{tabular}

$* p<0.1 ; * * p<0.05 ; * * * p<0.01$ 
Figure 1.

Wage differentials across the wage distribution. Native and immigrant men.

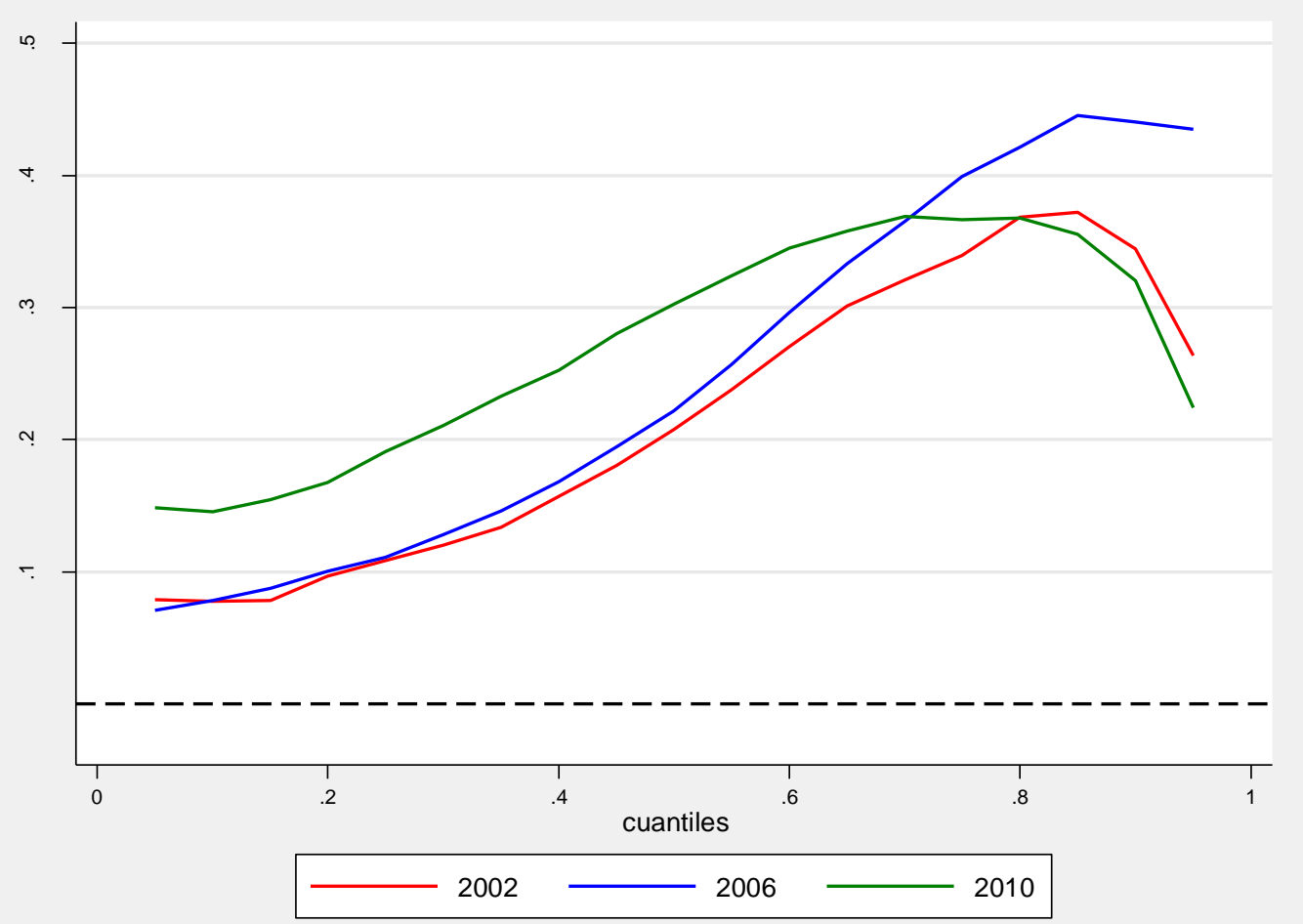


Figure 2.

Aggregate decomposition of wage differentials. Native and immigrant men. Fortin-Lemieux-Firpo decomposition. Model 1.

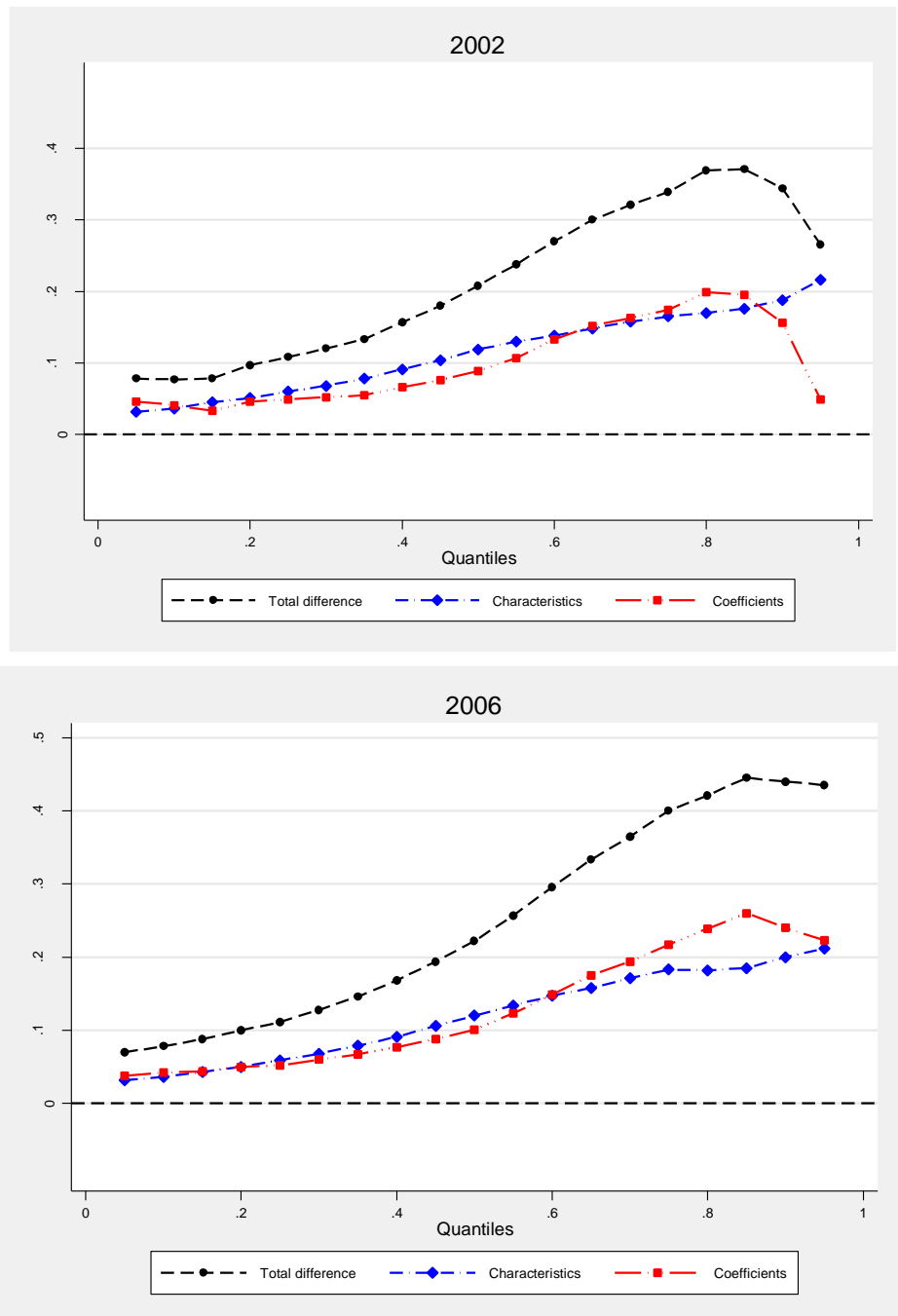

2010

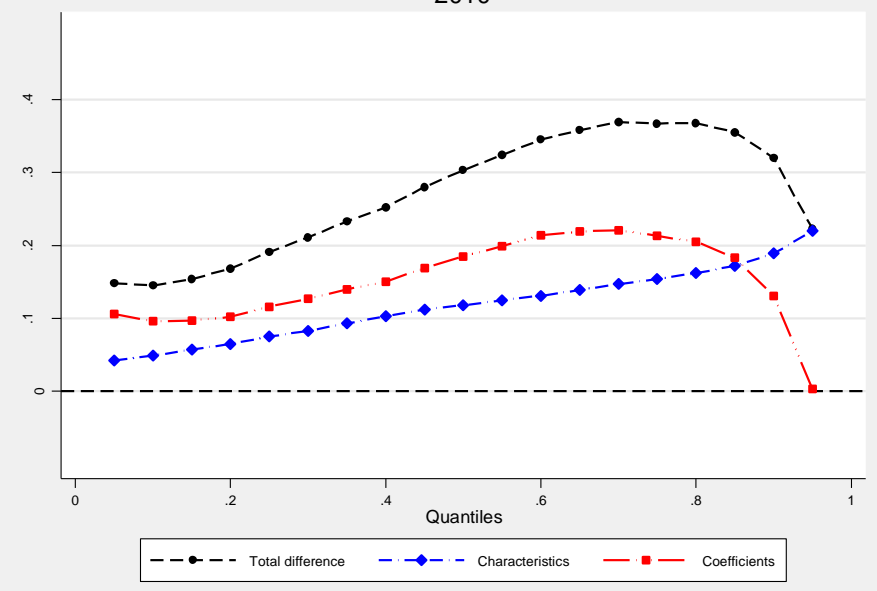

Notes: Model 1 includes as explanatory variables individual characteristics. 
Figure 3.

Aggregate decomposition of wage differentials. Native and immigrant men. Fortin-Lemieux-Firpo decomposition. Model 2.

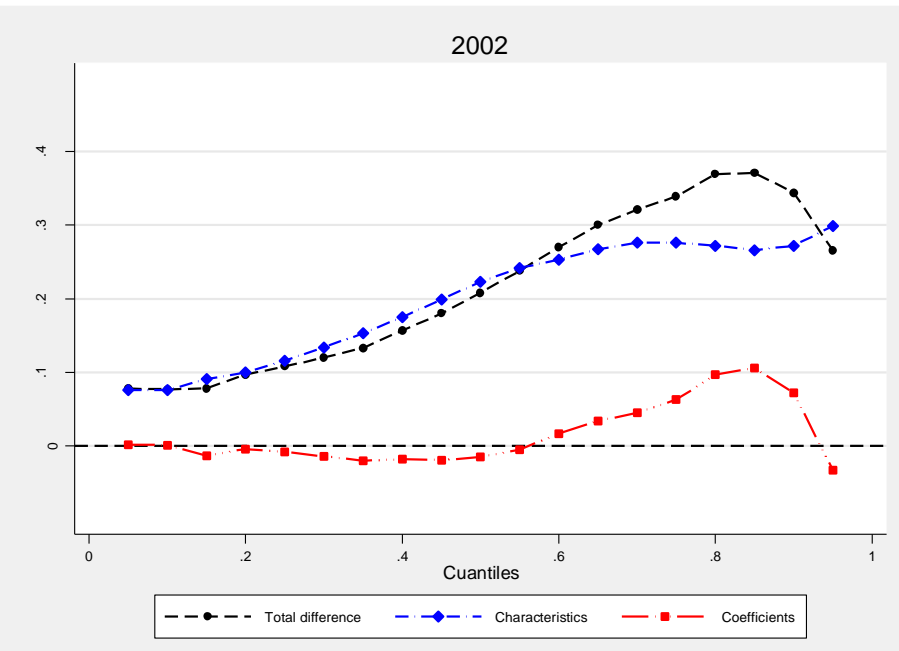

2006

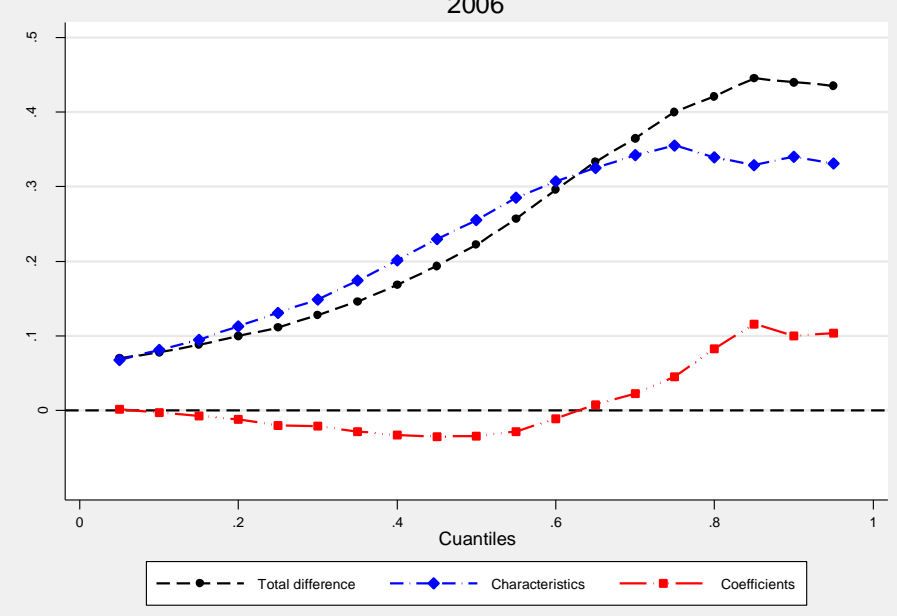

2010

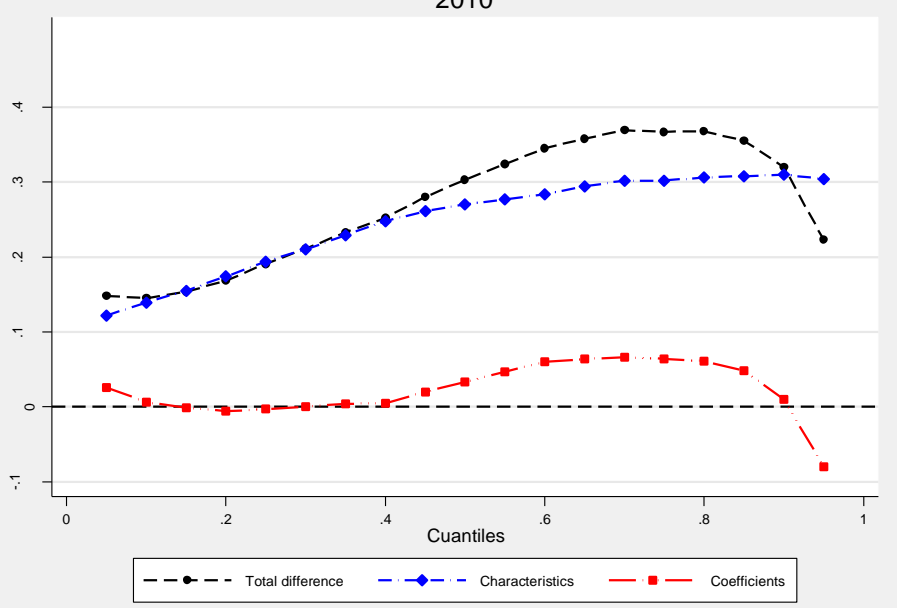

Notes: Model 2 includes as explanatory variables individual characteristics and job and firm attributes. 
Figure 4.

Detailed decomposition of wage differentials. Effect of the characteristics. Native and immigrant men. FortinLemieux-Firpo decomposition. Model 2.

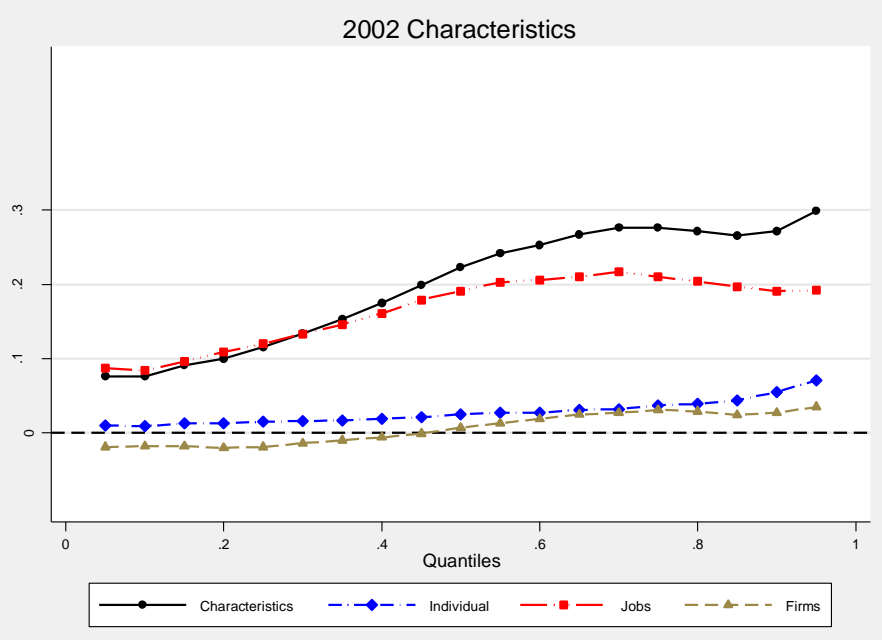

2006 Characteristics

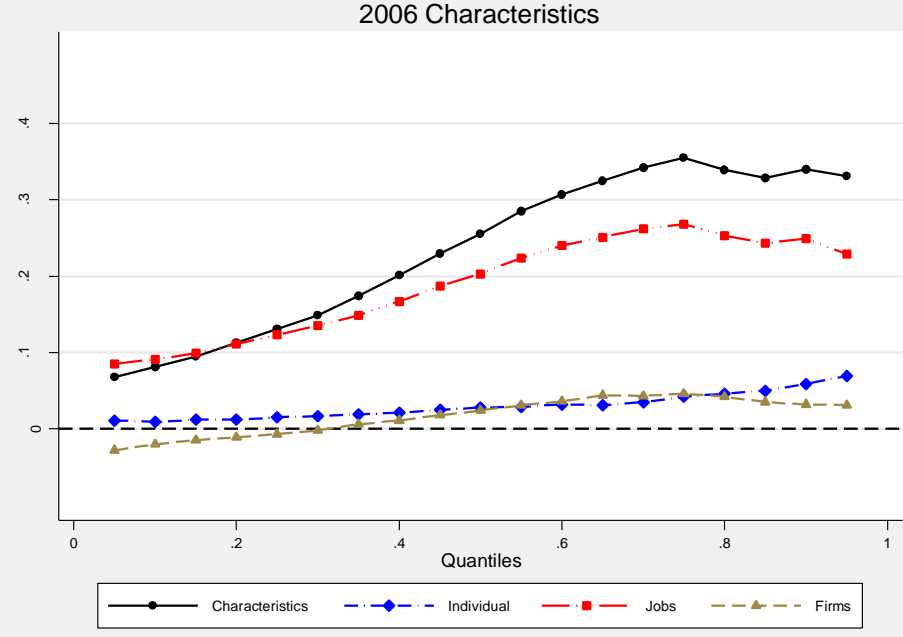

2010 Characteristics

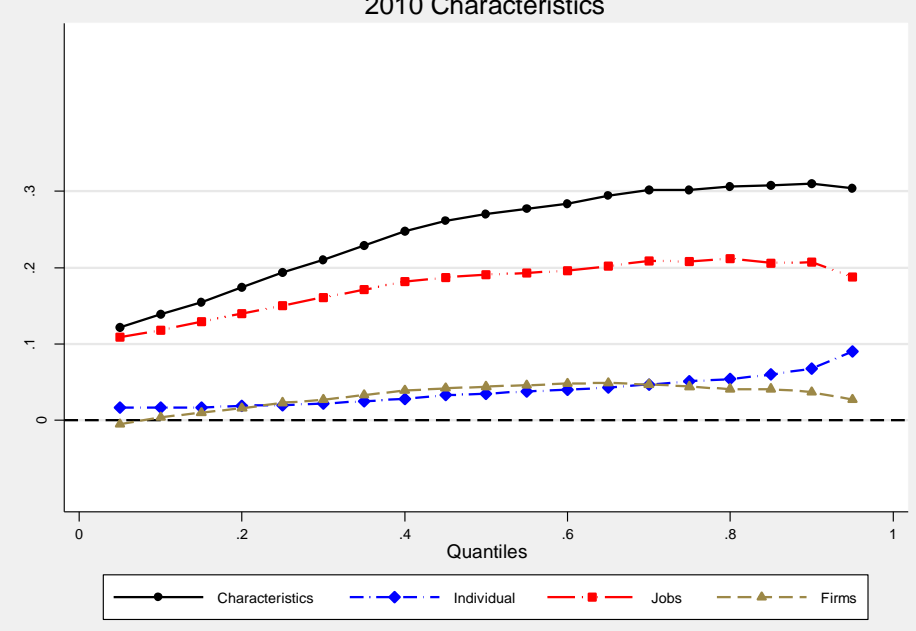

Notes: Model 2 includes as explanatory variables individual characteristics and job and firm attributes. 


\section{Appendix}

Figure A.1.

Kernel density functions of the logarithm of hourly wages of native and immigrant men.

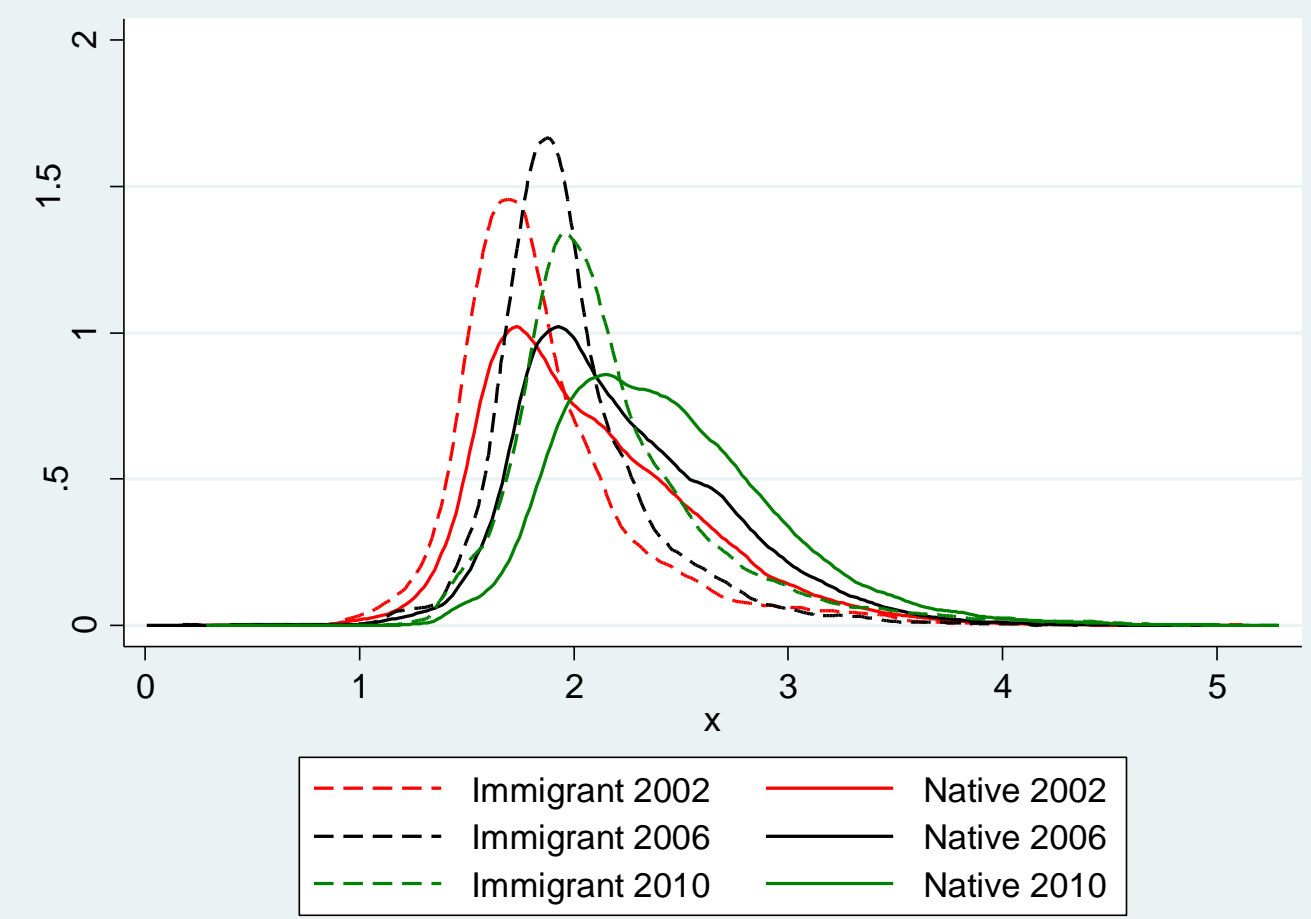

Notes: The figure includes the density function of the logarithm of the hourly wage. 
Table A.1.

Descriptive statistics. Native and immigrant men.

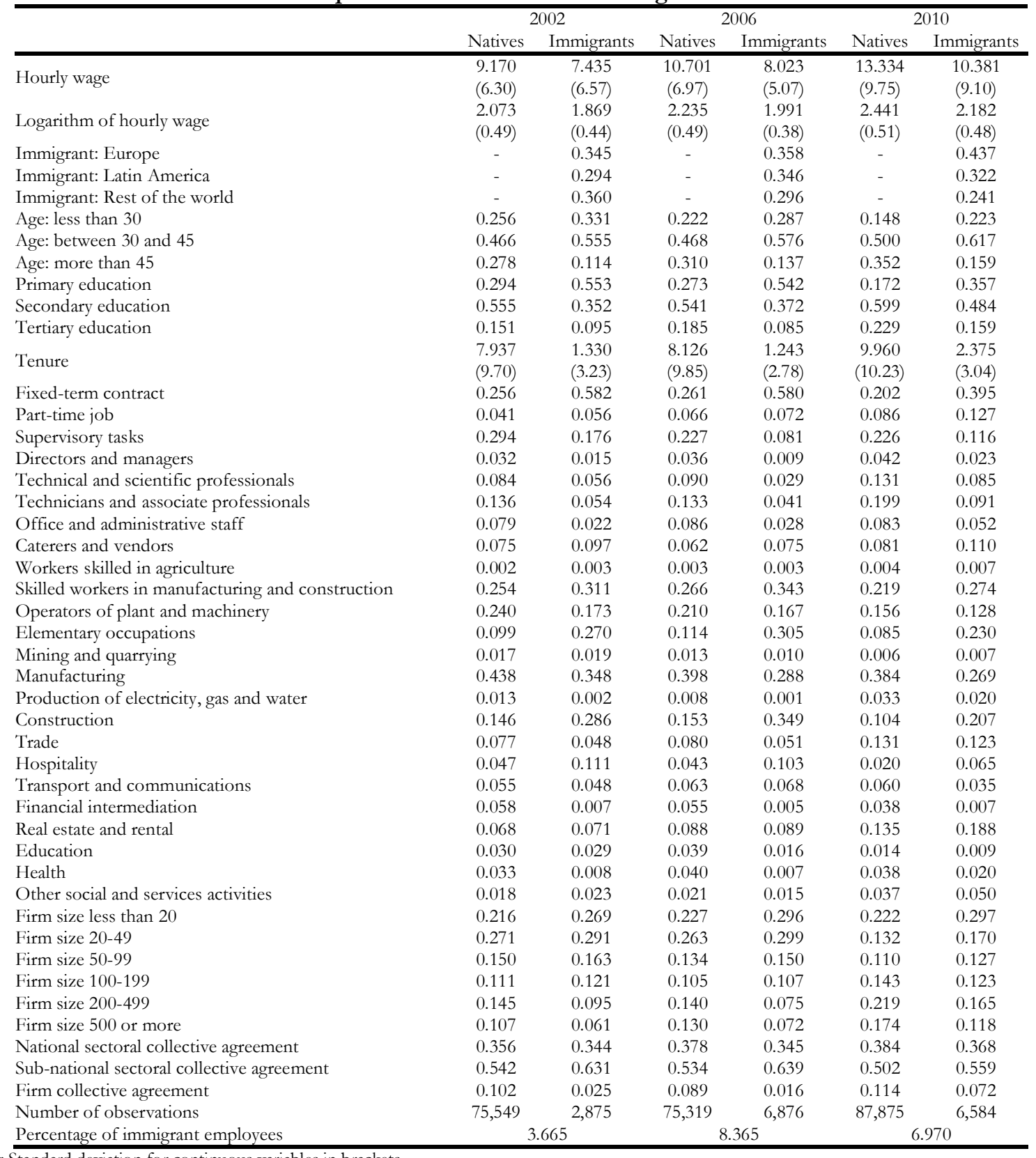

Table A.2.

Labour market status of immigrant men in Spain. Labour Force Survey.

\begin{tabular}{lcccccccccc}
\hline & \multicolumn{3}{c}{ Activity rate } & \multicolumn{4}{c}{ Employment rate } & \multicolumn{3}{c}{ Unemployment rate } \\
& 2002 & 2006 & 2010 & 2002 & 2006 & 2010 & 2002 & 2006 & 2010 \\
\hline Spaniards & 66.51 & 67.70 & 66.00 & 61.20 & 63.83 & 54.74 & 7.99 & 5.71 & 17.05 & \\
Immigrant & 84.83 & 85.61 & 84.86 & 73.43 & 78.32 & 58.92 & 13.45 & 8.52 & 30.57 \\
\hline
\end{tabular}

Notes: Information from the Labour Force Survey corresponds to the third quarter of the corresponding year. 
Table A.3.

Distribution of immigrant men by nationality in Spain.

Labour Force Survey and Structure of Earnings Survey.

\begin{tabular}{lcccccc}
\hline & \multicolumn{3}{c}{ LFS/Working age } & \multicolumn{3}{c}{ SES/Employees } \\
& 2002 & 2006 & 2010 & 2002 & 2006 & 2010 \\
\hline Spaniards & 94.67 & 89.51 & 87.35 & 96.33 & 91.63 & 93.03 \\
Immigrants & 5.02 & 9.97 & 11.57 & 3.67 & 8.37 & 6.97 \\
\hline
\end{tabular}

Notes: Information from the Labour Fore Survey and the Structure of Earnings Survey corresponds to the third quarter of the corresponding year. 